\section{'Ray Ruby' Grapefruit Affected by Huanglongbing II. Planting Density, Soil, and Foliar Nutrient Management}

\author{
Dinesh Phuyal \\ University of Florida, Institute of Food and Agricultural Sciences, Indian \\ River Research and Education Center, 2199 South Rock Road, Fort Pierce, \\ FL 34945
}

\section{Thiago Assis Rodrigues Nogueira}

São Paulo State University, School of Engineering, Department of Plant Protection, Rural Engineering and Soils, 56 Brasil Sul Avenue, Ilha Solteira, SP 15385-000, Brazil

Arun D. Jani

University of Florida, Institute of Food and Agricultural Sciences, Indian River Research and Education Center, 2199 South Rock Road, Fort Pierce, FL 34945

\section{Davie M. Kadyampakeni \\ University of Florida, Institute of Food and Agricultural Sciences, Citrus Research and Education Center, 700 Experiment Station Road, Lake Alfred, FL 33850}

\section{Kelly T. Morgan}

University of Florida, Institute of Food and Agricultural Sciences, Southwest Florida Research and Education Center, 2685 State Road 29 North, Immokalee, FL 34142

\section{Rhuanito Soranz Ferrarezi}

University of Florida, Institute of Food and Agricultural Sciences, Indian River Research and Education Center, 2199 South Rock Road, Fort Pierce, FL 34945

Additional index words. citrus greening, foliar application, fruit quality, fruit yield, highdensity, micronutrients

\begin{abstract}
Since the arrival of Huanglongbing (HLB) disease in Florida, several management approaches, including modification of orchard architecture design and nutritional therapy, have been explored. High-density plantings anticipate early economic returns from HLB-affected orchards. With no cure available for HLB, balanced nutrient application through soil and foliar spraying can mitigate the disease. A 2-year study was conducted to investigate the effects of three grapefruit (Citrus paradisi) planting densities [single-row (300 and 440 trees per ha), and doublerow high-density (975 trees per ha)], two controlled-release fertilizer (CRF) blends, and foliarapplied micronutrients (FAM) (a blend of $\mathrm{B}, \mathrm{Mn}$, and $\mathrm{Zn}$ at $0,1.5,3$, and 6 times the recommended rates) on grapefruit growth and fruit yield, physiological parameters, and foliar nutrient concentrations in an HLB-affected orchard. All the trees tested positive for HLB based on real-time quantitative polymerase chain reaction (qPCR) test. The highest planting density resulted in the lowest trunk diameter and canopy volume. Despite lower yield per tree in 201920, 975 trees per ha planting induced the greatest fruit and solid yields per ha. Also, the fruit produced from 975 trees per ha planting tended to be acidic with the deposition of more soluble solids. Use of CRF with higher micronutrients increased canopy volume with the expense of reduced fruit number in 2019-20. FAM did not affect cycle threshold $(\mathrm{Ct})$ value and tree growth parameters. Fruit yield, photosynthesis rate, and stomatal conductance $\left(g_{\mathrm{S}}\right)$ decreased, and all leaf nutrient concentrations except B increased in 2019-20 with all FAM rates tested. In conclusion, our study showed that high-density planting optimizes yield under HLB-endemic conditions. In addition, supplemental soil and foliar micronutrient application do not enhance yield of HLB-affected trees over a 2-year timeframe, warranting further research for confirmation of results.
\end{abstract}

Growers have been using advanced horticultural practices and modifying orchard architecture design to cope with the Huanglongbing (HLB) epidemic in Florida. High-

density planting is one modification that can potentially anticipate early economic returns (Roka et al., 2009; Singerman et al., 2018; Stover et al., 2008), which is important because of the high probability of HLBinduced fruit yield reductions in later years. Previous work has shown that high-density plantings can increase fruit yield in mandarin (Citrus nobilis $\times$ Citrus deliciosa), sweet orange (Citrus sinensis), lime (Citrus aurantifolia), and grapefruit (C. paradisi) (Dalal et al., 2013; Ladaniya et al., 2020; Moreira et al., 2019; Phuyal et al., 2020; Singerman et al., 2018). The past studies were limited to tree density only, and scarce literature is available about the effect of high-density plantings with conjunction of soil and foliar nutrient application on grapefruit tree health, fruit yield, and fruit quality.

Citrus tree physiological function is negatively impacted by HLB (Etxeberria et al., 2009; Gonzalez et al., 2012). Nwugo et al. (2013) found that HLB-affected grapefruit showed alteration of several foliar proteins due to nutrient deficiency. Conversely, nutrient management can improve physiological function in HLB-affected citrus. Li et al. (2014) showed that a higher application rate of zinc $(\mathrm{Zn})$ can increase photosynthetic rates and $g_{\mathrm{S}}$ of HLB-affected grapefruit seedlings under hydroponic conditions. In addition, Yang et al. (2012) observed reduced carbon dioxide $\left(\mathrm{CO}_{2}\right)$ assimilation in magnesium (Mg)-deficient pomelo (Citrus grandis), possibly due to the decrease in photosynthetic electron transport capacity.

As an essential constituent of chlorophyll, $\mathrm{Mg}$ is involved in photosynthesis, enzyme activation, protein synthesis, carbohydrate partitioning, and plant growth, playing an important role in resistance mechanisms against bacterial and fungal diseases (Huber and Jones, 2013; Marschner, 2012). Magnesium deficiency in citrus results in the impairment of photosynthesis in leaves, alterations of gas exchange, and metabolite imbalance in the tree (Li et al., 2017; Tang et al., 2012). Application of $\mathrm{Mg}$ in $\mathrm{Mg}$ deficient soil can improve the quality of horticultural crop products, especially when the quality traits are dependent on photosynthesis and assimilate translocation processes regulated by $\mathrm{Mg}$ within the plant system (Gerendás and Führs, 2013).

Foliar nutrient application is important during citrus reproductive stages to enhance fruit yield and quality. When soil properties are not conducive to nutrient uptake (temperature extremes, low or excess soil moisture, $\mathrm{pH}$, and salinity), foliar applications can meet nutrient demand. Compared with soil application, foliar nutrient application can potentially reduce nutrient runoff, thereby reducing negative environmental impacts (Lovatt, 1999, 2013). FAM is especially important for citrus trees grown in calcareous soils, because they typically show micronutrient deficiency symptoms, namely for iron $(\mathrm{Fe})$ and $\mathrm{Zn}$. High soil $\mathrm{pH}$ limits the uptake of micronutrients, and foliar application accelerates the process of nutrient acquisition to correct deficiencies (Ibrahim et al., 2007).

Several studies have demonstrated the benefits of FAM in citrus orchards. Labanauskas (1963) reported that manganese $(\mathrm{Mn})$ and $\mathrm{Zn}$ deficiency in grapefruit can be 
corrected by foliar spray of those nutrients. Morgan and Kadyampakeni (2020) suggested $\mathrm{Zn}$ deficiency should be corrected by only foliar spray on calcareous soils as the alkaline $\mathrm{pH}$ halts soil available $\mathrm{Zn}$. Boaretto et al. (1997) showed that foliar boron (B) application increased leaf $B$ concentration of sweet orange to an adequate range without affecting fruit yield or quality. Similar findings with $\mathrm{Zn}$ were reported by Boaretto et al. (2002). A study by Morgan et al. (2016) found that spraying of $\mathrm{B}, \mathrm{Mn}$, and $\mathrm{Zn}$ increased the leaf concentrations of those micronutrients in 6-year-old 'Valencia' sweet orange trees on Swingle citrumelo rootstock $(C$. paradisi $\times$ Poncirus trifoliata $)$.

Foliar application alone or in combination with other substances such as hormones and insecticides has been shown to increase citrus fruit yield. Several authors noted higher fruit yield of 'Valencia' sweet orange with the application of insecticides and foliar nutrients (Stansly et al., 2014; Tansey et al., 2017). Morgan et al. (2016) reported that foliar application containing $3 \times$ the recommended rate of $\mathrm{Mn}$ increased fruit yield in 6-year-old 'Valencia' sweet orange in a fiveyear study. Rouse et al. (2017) observed that increasing foliar nutrient application rates enhanced 'Valencia' sweet orange fruit yield, while Al-Obeed et al. (2018) showed that foliar application of $\mathrm{B}$ and $\mathrm{Zn}$ increased mandarin (Citrus reticulata) fruit yield and quality.

Foliar nutrient application can also mitigate disease expression. Pustika et al. (2008) observed reduced disease symptoms on mandarin trees affected with HLB with foliar nutrient application. Shen et al. (2013) observed increased disease resistance, higher $\mathrm{Ct}$ value, and improved canopy size in 'Valencia' orange with long-term application of foliar nutrients along with salicylic acid and phosphite.

Balanced application of nutrients to correct deficiencies is an important tool to control biotic and abiotic stresses as well as to improve nutrient use efficiency (Zekri and

Received for publication 24 June 2020. Accepted for publication 25 June 2020.

Published online 31 July 2020

This research was funded by the UF/IFAS Citrus Initiative and in part by the U.S. Department of Agriculture (USDA)-APHIS-MAC Agreement No. AP19PPOSandT00C116.

We thank Dr. Mark Ritenour, Dr. Jude Grosser, Tom James, Randy Burton, Hernan Soto, Cristina Gil, Andres Gonzalez, Clarence King, Donald Davis, Taylor Meadows, Megan Eckman, Benjamin Holly, and Peter Spyke for the treatment application, research field maintenance, and data collection. We also thank Southern Gardens Diagnostic Laboratory (Mike Irey) and Citrus Research and Development Foundation for the real-time quantitative polymerase chain reaction (qPCR) testing.

R.S.F. is the corresponding author. E-mail: rferrarezi@ ufl.edu.

This is an open access article distributed under the CC BY-NC-ND license (https://creativecommons.org/ licenses/by-nc-nd/4.0/).
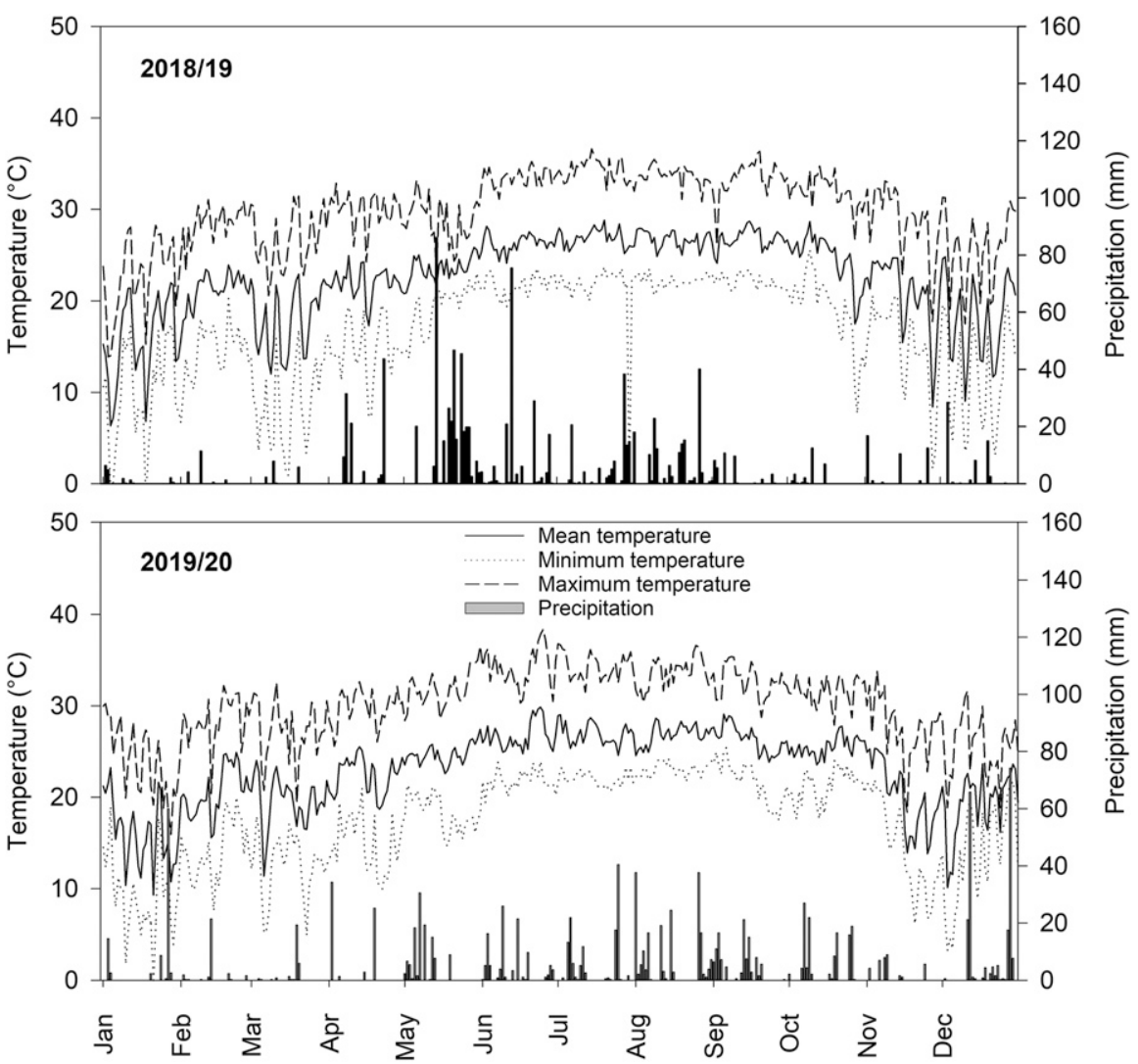

Fig. 1. Monthly accumulated rainfall precipitation, mean, minimum, and maximum temperatures recorded in 2018-19 and 2019-20.

Obreza, 2018, 2019). The efficiency of enhanced nutritional programs on HLBaffected trees is site- and variety-specific with some studies showing no effect of those substances for mitigating disease, increasing fruit yield, and improving fruit quality (Gottwald et al., 2012). There is limited information available about high plant density and the joint use of soil and foliar nutrients on HLB-affected grapefruit. Nevertheless, it is hypothesized that nutrients, especially $\mathrm{Mg}$ and micronutrients, applied to grapefruit affected by HLB can increase fruit yield and reduce disease incidence by improving physiological parameters.

The objective of this study was to evaluate the effects of tree planting density, soil $\mathrm{Mg}$ and micronutrient application, and FAM on grapefruit growth and fruit yield parameters, physiological response, and HLB disease.

\section{Materials and Methods}

Study site. A large-scale field trial was conducted from 2018 to 2020 at the University of Florida Institute of Food and Agricultural Sciences (UF/IFAS) Indian River Research and Education Center research farm in Fort Pierce, FL (lat. $27^{\circ} 26^{\prime} 08.2^{\prime \prime} \mathrm{N}$, long. $80^{\circ} 26^{\prime} 43.2^{\prime \prime} \mathrm{W}$, and elevation of $8 \mathrm{~m}$ ). Weather data were collected by using the Florida Automated Weather Network (FAWN) station in St. Lucie West (Fig. 1). Soil moisture was monitored during the study using soil moisture sensors (TDT ACC-SENSDI; Acclima Inc., Meridian, ID) placed
$0.6 \mathrm{~m}$ away from the main trunk and $15 \mathrm{~cm}$ below the soil surface, where maximum root activity was observed. Sensors were connected to a datalogger (CR 205; Campbell Scientific Inc., Logan, UT) programmed to collect data at 15 -min intervals. The datalogger was connected to a rechargeable battery (6FM7; Toyo, Tonawanda, NY) and solar panel (HY015-12P; Acopower, Walnut, CA) mounted on a pole. The data were averaged according to the treatments (Fig. 2).

Plant material. Five-year-old 'Ray Ruby' grapefruit trees on Kuharske citrange $(C$. sinensis $\times P$. trifoliata) rootstock planted in Sept. 2013 were used as planting material. The study was conducted for two seasons (2018-19 and 2019-20).

Experimental design and treatments. The experiment was conducted using a splitsplit-plot design with four replications. We tested three planting densities, two CRF blends, and four FAM rates. Planting densities were as follows: 1) 300 trees per ha, single-row low-density (SR/LD); 2) 440 trees per ha, single-row high-density (SR/ HD); and 3) 975 trees per ha, double-row high-density (DR/HD).

In 2018-19, we tested two CRF blends [16 nitrogen $(\mathrm{N})-1.31$ phosphorus $(\mathrm{P})-16.6$ potassium $(\mathrm{K})$ and $12 \mathrm{~N}-1.31 \mathrm{P}-7.47 \mathrm{~K}]$, while in 2019-20, both CRF blends were adjusted according to University of Florida/Institute of Food and Agricultural Science (UF/IFAS) recommendation, and made [12-3-14 (12N$1.31 \mathrm{P}-11.62 \mathrm{~K}$ ) with $70 \%$ of $\mathrm{N}$ as a CRF and other micronutrients as sulfates; and 12-3-14 

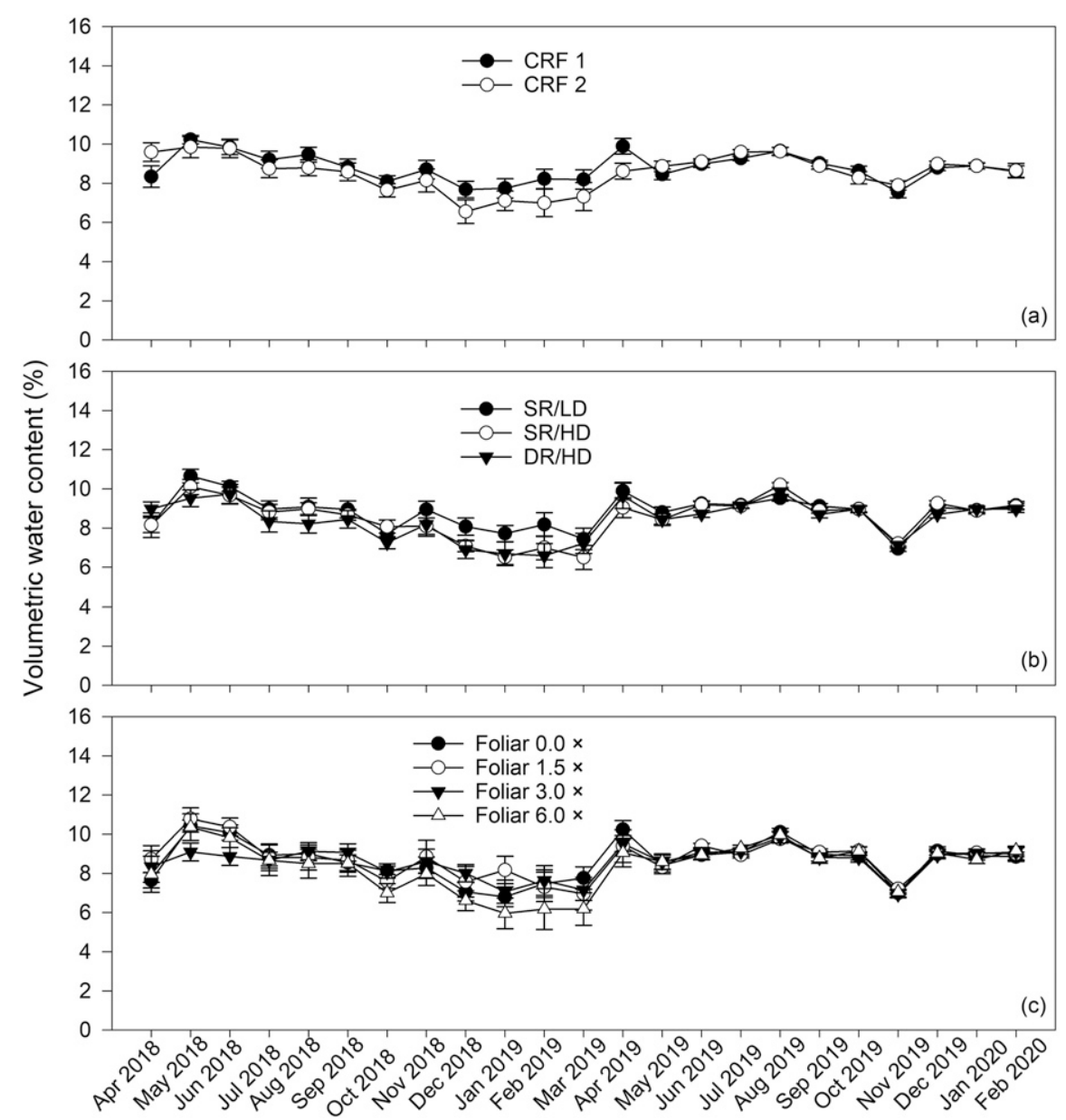

Fig. 2. Volumetric water content reading during the experiment. Two different controlled-release fertilizer (CRF) blends [12-3-9 (12N-1.31P-7.47K) with all micronutrients as sulfur-coated products at higher rates; and 16-3-20 (16N-1.31P-16.6K) with all micronutrients as sulfates] in 2018-19 and two CRF blends [12-3-14 (12N-1.31P-11.62 K) with 2 times of $\mathrm{Mg}$ and 2.5 times of recommended rates; and 12-3-14 (12N-1.31P-11.62 K) with the recommended rate for $\mathrm{Mg}$ and all micronutrients] in 2019-20 (A), three planting density [single-row low-density (SR/LD, 300 trees per ha), single-row high-density (SR/HD, 440 trees per ha), and double-row high-density staggered in diamond setting (DR/HD, 975 trees per ha) $]$ (B), and four foliar treatments $(0,1.5,3$, and 6 times) of recommended rates of $\mathrm{B}, \mathrm{Mn}$, and $\mathrm{Zn}(\mathbf{C})$. Each point represents mean \pm SE.

Table 1. Nutrient application rates for controlled-release fertilizer (CRF) blends used in the study.

\begin{tabular}{|c|c|c|c|c|}
\hline & \multicolumn{2}{|c|}{ CRF 1 amount $\left(\mathrm{kg} \cdot \mathrm{ha}^{-1}\right)$} & \multicolumn{2}{|c|}{ CRF 2 amount $\left(\mathrm{kg} \cdot \mathrm{ha}^{-1}\right)$} \\
\hline & $2018-19$ & $2019-20$ & $2018-19$ & $2019-20$ \\
\hline $\mathrm{N}$ & 180 & 180 & 180 & 180 \\
\hline $\mathrm{P}_{2} \mathrm{O}_{5}$ & 45 & 44.82 & 34 & 44.82 \\
\hline $\mathrm{K}_{2} \mathrm{O}$ & 135 & 209.17 & 225 & 209.17 \\
\hline $\mathrm{Ca}$ & 30 & 14.94 & 11 & 14.94 \\
\hline $\mathrm{Mg}$ & 35 & 36.07 & 16 & 18.08 \\
\hline $\mathrm{S}$ & 223 & 227.83 & 73 & 194.34 \\
\hline B & 1.09 & 1.69 & 10.67 & 0.67 \\
\hline $\mathrm{Cu}$ & 0.60 & 1.49 & 0 & 0.60 \\
\hline $\mathrm{Fe}$ & 15.58 & 14.72 & 5.88 & 5.89 \\
\hline $\mathrm{Mn}$ & 18.90 & 21.04 & 17.82 & 8.41 \\
\hline Mo & 0.09 & 0.22 & 0 & 0 \\
\hline $\mathrm{Zn}$ & 7.32 & 14.72 & 5.88 & 5.89 \\
\hline
\end{tabular}

$(12 \mathrm{~N}-1.31 \mathrm{P}-11.62 \mathrm{~K})$ with 2 times $\mathrm{Mg}$ and 2.5 times the recommended rates of micronutrients with $70 \%$ of $\mathrm{N}$ as a CRF and other micronutrients as sulfates] (Table 1). Both seasons, CRF blends were applied in February, July, and October, with the amount based on recommended $\mathrm{N}$ rates for mature grapefruit trees in Florida (Morgan and Kadyampakeni, 2020).
$\left[\left(\mathrm{Na}_{2} \mathrm{~B}_{8} \mathrm{O}_{13} \cdot 4 \mathrm{H}_{2} \mathrm{O}\right)\right.$ with $21 \%$ of $\left.\left.\mathrm{B}\right]\right\}$ were sprayed in March, May, and September during growth flushes as suggested by Morgan et al. (2016).

Field preparation and orchard layout. The orchard architecture design and cultural practices followed were the same as indicated by Phuyal et al. (2020) because the studies were conducted in sequence in the same area. There were 96 experimental units each measuring $15.24 \times 29.12 \mathrm{~m}$.

Concentration of Candidatus Liberibacter asiaticus DNA in plant leaf tissue. Eight random trees were chosen excluding border trees to collect leaf samples. The samples were collected in April and analyzed by realtime qPCR. The processes to collect and analyze leaf samples are detailed in Phuyal et al. (2020). Ct value was assessed in which less than 32 is considered as and HLBpositive tree.

Tree growth measurement. Four trees were selected randomly in each plot excluding the border trees to measure the tree height, canopy diameter and trunk diameter following Phuyal et al. (2020). Canopy volume was calculated by using geometric prolate spheroid equation: [(4/3) $(\pi)$ (tree height/ 2 ) (average canopy diameter)2] (Obreza and Rouse, 1993)

Fruit yield and fruit size. We selected four random trees from each plot to measure fruit yield (excluding the border trees). Fruit yield per tree, fruit yield per unit area, and fruit diameter were determined by using an optical sizer (Autoline, Reedley, CA) following Phuyal et al. (2020). Fruit size was categorized based on commercial categories of grapefruit (number of fruit per carton) and grouped in size 48 and smaller $(<100 \mathrm{~mm})$, size 40-27 (100-117 mm), and size 23 and larger (>117 mm) (Ferrarezi et al., 2019).

Fruit quality and yield of solids. The fruit acidity, soluble solids, ratio, and yield of solids were determined. The methods are available in Phuyal et al. (2020).

Plant photosynthesis measurement. Photosynthesis rate, $g_{\mathrm{S}}$, intercellular $\mathrm{CO}_{2}$, and transpiration rate were measured in April 2019 on two randomly selected trees per plot by using an infrared gas analyzer (LI-COR 6400XT; LI-COR Inc., Lincoln, NE). Two measurements were taken one week after FAM from 10:00 AM to 2:00 PM on sunny days from each sampled tree on different branches. Leaves were selected from a sunlit portion of the canopy. Immature, diseased, insect-damaged, mechanically injured, or dead leaves were avoided. Measurements were carried out in fully expanded mature citrus leaves as suggested by Iglesias et al. (2002). A constant flow rate of $500 \mu \mathrm{mol} \cdot \mathrm{s}^{-1}$, at 50 to $80 \%$ relative humidity, ambient reference $\mathrm{CO}_{2}$, and photosynthetically active radiation was adjusted in the leaf chamber of the gas analyzer. The leaf was clamped in the leaf chamber until the steady-state photosynthesis level was reached.

Leaf sampling for nutrient analysis. Eight random trees were chosen excluding border trees to collect leaf samples. The leaf samples 
were collected in August to analyze for leaf nutrient concentration. The protocol to collect, preserve, and analyze leaf samples are available in Phuyal et al. (2020).

Soil sampling and analysis. One $20-\mathrm{cm}$ deep soil core/tree in 15 different locations/ plot was taken in February to access the available soil nutrients and $\mathrm{pH}$. Analysis followed methods available in Phuyal et al. (2020) and Mehlich (1984).
Statistical analysis. Statistical analysis was performed using SAS 9.4 (SAS Institute Inc., Cary, NC). Data were analyzed by year for two consecutive seasons. A generalized linear mixed model (Proc GLIMMIX) was used to analyze error variance where treatments were entered as fixed effect and block as a random effect. The data were checked for assumptions of the linear model. Fruit yield and yield of solids data were not normally distributed, and were transformed to square root and $\log$, respectively, to meet the assumptions of normality and homoscedasticity. Tukey test was used for multiple mean comparisons $(P<0.05)$. Correlations were calculated to find the relationship between the amount of foliar application with the total number of fruit yield per tree and per area (Proc CORR).
Table 2. Cycle threshold (Ct) value of Candidatus Liberibacter asiaticus (CLas) DNA as a function of controlled-release fertilizer (CRF), planting density (PD), and foliar-applied micronutrients (FAM).

\begin{tabular}{|c|c|c|}
\hline \multirow[b]{2}{*}{ Treatments } & \multicolumn{2}{|c|}{ Ct value of CLas DNA (unitless) } \\
\hline & $2018-19$ & $2019-20$ \\
\hline \multicolumn{3}{|l|}{$\overline{\mathrm{CRF}}^{\mathrm{z}}$} \\
\hline CRF 1 & $24.95 \pm 0.24^{\mathrm{w}}$ & $29.88 \pm 0.17$ \\
\hline CRF 2 & $24.94 \pm 0.26$ & $29.96 \pm 0.16$ \\
\hline \multicolumn{3}{|l|}{$\mathrm{PD}^{\mathrm{y}}$} \\
\hline $\mathrm{SR} / \mathrm{LD}$ & $25.12 \pm 0.39$ & $29.83 \pm 0.22$ \\
\hline $\mathrm{SR} / \mathrm{HD}$ & $24.91 \pm 0.27$ & $30.10 \pm 0.20$ \\
\hline $\mathrm{DR} / \mathrm{HD}$ & $24.82 \pm 0.28$ & $29.82 \pm 0.19$ \\
\hline \multicolumn{3}{|l|}{ FAM $^{x}$} \\
\hline $0.0 \times$ & $25.07 \pm 0.34$ & $29.98 \pm 0.22$ \\
\hline $1.5 \times$ & $25.13 \pm 0.41$ & $30.01 \pm 0.24$ \\
\hline $3.0 \times$ & $24.64 \pm 0.34$ & $30.03 \pm 0.25$ \\
\hline $6.0 \times$ & $24.96 \pm 0.34$ & $29.66 \pm 0.24$ \\
\hline Sources of variation & \multicolumn{2}{|c|}{$P$ value } \\
\hline CRF & NS & NS \\
\hline PD & NS & NS \\
\hline CRF*PD & NS & NS \\
\hline FAM & ns & NS \\
\hline CRF*FAM & NS & NS \\
\hline PD*FAM & NS & NS \\
\hline CRF*PD*FAM & NS & NS \\
\hline \multicolumn{3}{|c|}{ 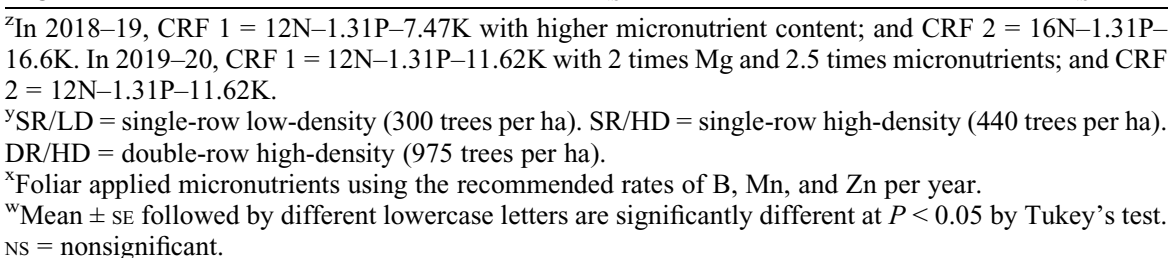 } \\
\hline
\end{tabular}

\section{Results}

Candidatus Liberibacter asiaticus infection. Planting density, CRF application, and FAM did not influence $\mathrm{Ct}$ values of Candidatus Liberibacter asiaticus ( $C$ Las) DNA (Table 2, $P>0.05$ ). All sampled trees were infected since values were below 32 (Albrecht and Bowman, 2011; Gottwald et al., 2012; Shin and van Bruggen, 2018).

Tree growth. Canopy volume and trunk diameter were both affected by planting density $(P<0.0001)$. Depending on season, canopy volume was $31 \%$ to $37 \%$ lower under $\mathrm{DR} / \mathrm{HD}$ than under $\mathrm{SR} / \mathrm{LD}$ and $\mathrm{SR} / \mathrm{HD}$ (Table 3). Similarly, trunk diameter was $13 \%$ to $17 \%$ smaller under DR/HD than under SR/HD and SR/LD. Canopy volume, but not trunk diameter, was also affected by CRF blends. We found that CRF 1 resulted in $10 \%$ and $8 \%$ greater canopy volume than CRF 2 in 2018-19 and 2019-20, respectively (Table 3). Canopy volume was unaffected by foliar micronutrient application $(P>0.05)$.

Fruit yield and fruit size. For both seasons, the greatest fruit yields were obtained with DR/HD, which was $136 \%$ to $190 \%$ higher than under SR/LD (Table 4). Higher micronutrient application through CRF blends reduced the number of fruit in 2019-

Table 3. Trunk diameter and canopy volume as a function of controlled-release fertilizer (CRF), planting density (PD), and foliar-applied micronutrients (FAM).

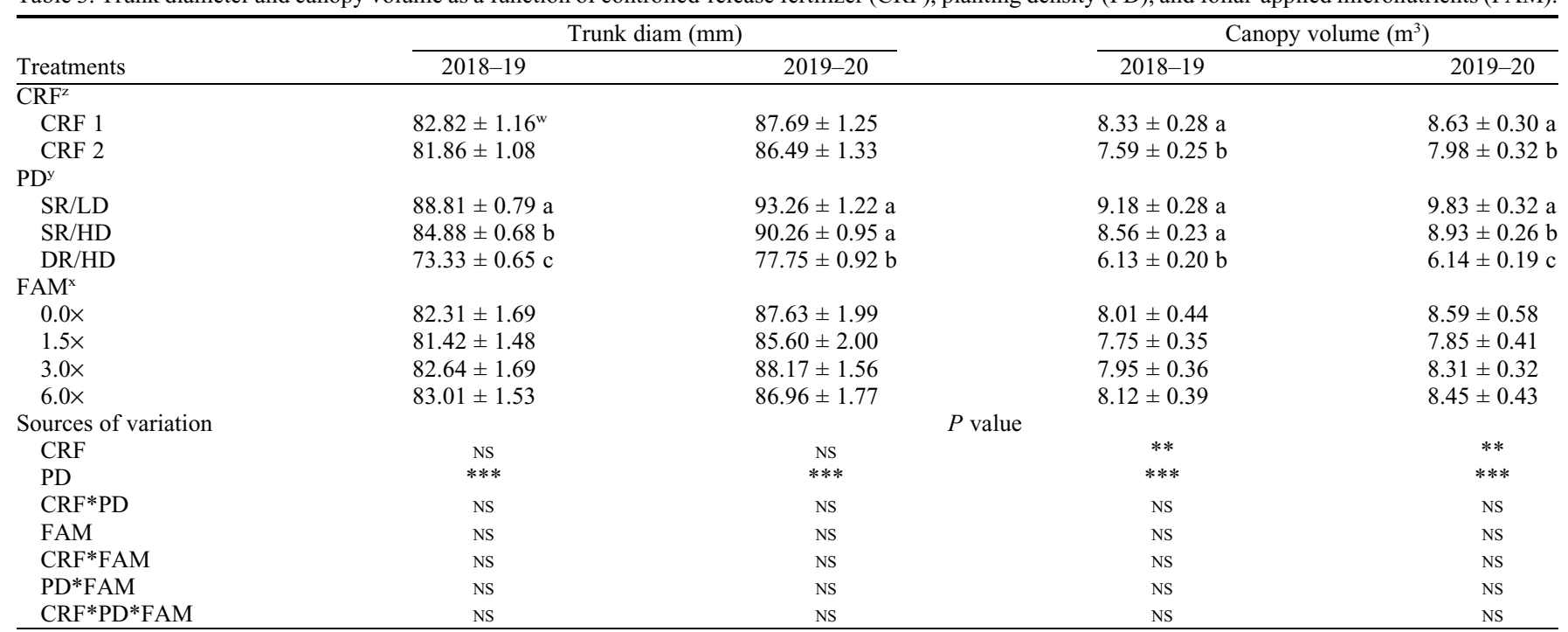

${ }^{\mathrm{Z}}$ In $2018-19$, CRF $1=12 \mathrm{~N}-1.31 \mathrm{P}-7.47 \mathrm{~K}$ with higher micronutrient content; and CRF $2=16 \mathrm{~N}-1.31 \mathrm{P}-16.6 \mathrm{~K}$. In $2019-20$, CRF $1=12 \mathrm{~N}-1.31 \mathrm{P}-11.62 \mathrm{~K}$ with 2 times $\mathrm{Mg}$ and 2.5 times micronutrients; and $\mathrm{CRF} 2=12 \mathrm{~N}-1.31 \mathrm{P}-11.62 \mathrm{~K}$.

${ }^{\mathrm{y}} \mathrm{SR} / \mathrm{LD}=$ single-row low-density (300 trees per ha). SR/HD = single-row high-density (440 trees per ha). DR/HD = double-row high-density $(975$ trees per ha).

${ }^{\mathrm{x}}$ Foliar applied micronutrients using the recommended rates of $\mathrm{B}, \mathrm{Mn}$, and $\mathrm{Zn}$ per year.

${ }^{\mathrm{w}}$ Mean \pm SE followed by different lowercase letters are significantly different at $P<0.05$ by Tukey's test.

Ns, ${ }^{* *},{ }^{* * *}$ Nonsignificant or significant at $P<0.01$ or 0.001 , respectively. 
Table 4. Fruit diameter, fruit yield per tree, and fruit yield per area as a function of controlled-release fertilizer (CRF), planting density (PD), and foliar-applied micronutrients (FAM).

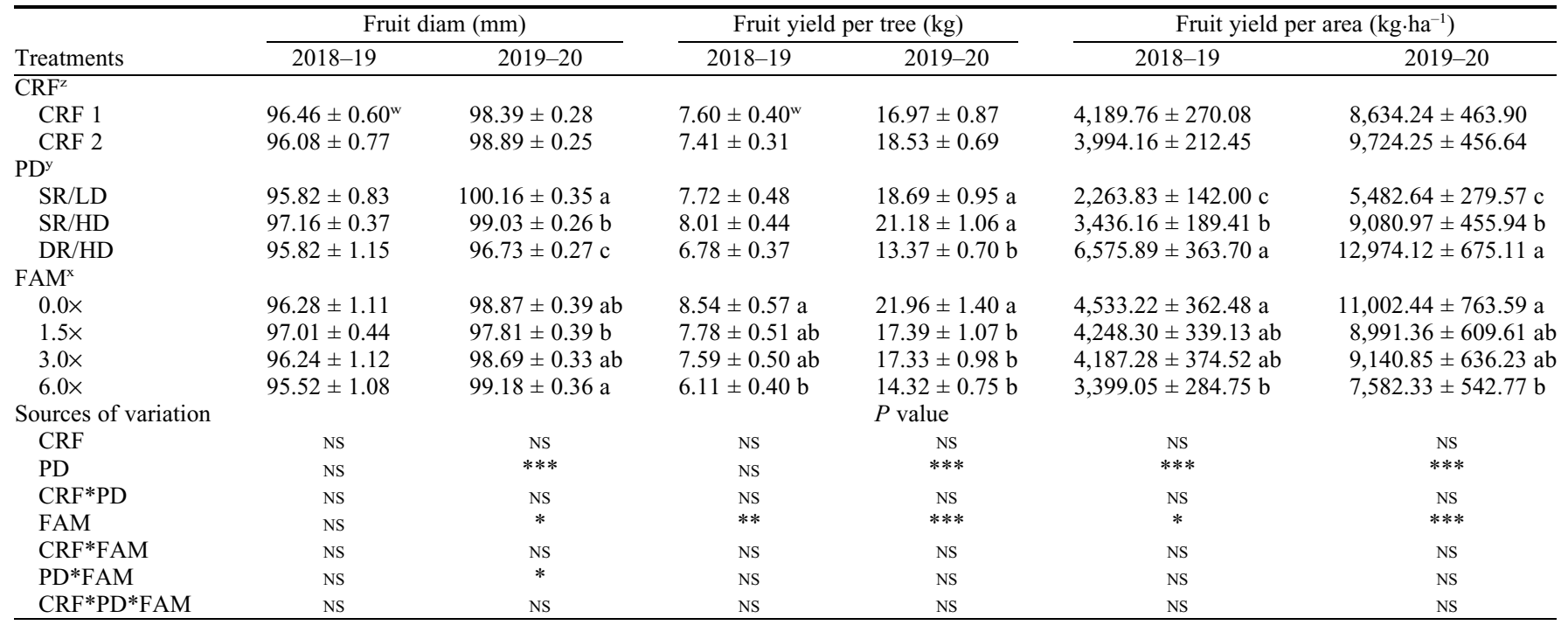

${ }_{\mathrm{z}} \mathrm{In} 2018-19$, CRF $1=12 \mathrm{~N}-1.31 \mathrm{P}-7.47 \mathrm{~K}$ with higher micronutrient content; and CRF $2=16 \mathrm{~N}-1.31 \mathrm{P}-16.6 \mathrm{~K}$. In 2019-20, CRF $1=12 \mathrm{~N}-1.31 \mathrm{P}-11.62 \mathrm{~K}$ with 2 times $\mathrm{Mg}$ and 2.5 times micronutrients; and $\mathrm{CRF} 2=12 \mathrm{~N}-1.31 \mathrm{P}-11.62 \mathrm{~K}$.

${ }^{\mathrm{y}} \mathrm{SR} / \mathrm{LD}=$ single-row low-density (300 trees per ha). SR/HD = single-row high-density (440 trees per ha). $\mathrm{DR} / \mathrm{HD}=$ double-row high-density $(975$ trees per ha)

${ }^{\mathrm{x}}$ Foliar applied micronutrients using the recommended rates of $\mathrm{B}, \mathrm{Mn}$, and $\mathrm{Zn}$ per year.

${ }^{\mathrm{w}}$ Mean $\pm \mathrm{SE}$ followed by different lowercase letters are significantly different at $P<0.05$ by Tukey's test.

Ns, *,**,***Nonsignificant or significant at $P<0.05,0.01$, or 0.001 , respectively.

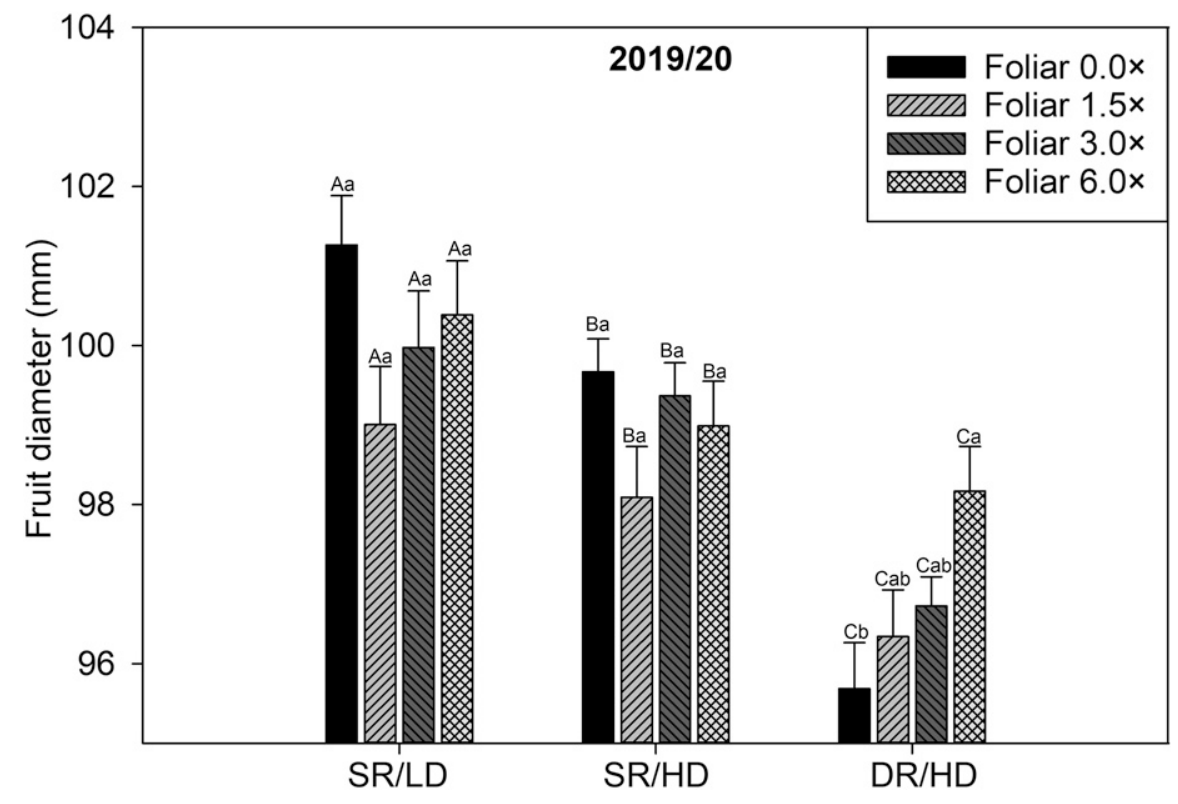

Fig. 3. Fruit diameter under three planting density (PD) [single-row low-density (SR/LD, 300 trees per ha), single-row high-density (SR/HD, 440 trees per ha), and double-row high-density staggered in diamond setting (DR/HD, 975 trees per ha)]; and four foliar-applied micronutrient rates (FAM) $(0,1.5,3$, and 6 times) as a blend of $\mathrm{B}, \mathrm{Mn}$, and $\mathrm{Zn}$ according to the UF/IFAS year recommended rates. Means $\pm \mathrm{SE}$ followed by different letters (uppercase compare FAM and lowercase compare PD) are significantly different by Tukey's test at $P<0.05$.

20. Foliar nutrient application was negatively correlated with fruit yields in 2018-19 $(r=$ $-0.122, P=0.0168)$ and $2019-20(r=-0.176$, $P=0.0005)$ and total fruit number (Table 5). In 2019-20, an interaction between planting densities and FAM micronutrient applications was observed, with SR/LD producing the largest-diameter fruit compared with other treatments (Fig. 3).
Fruit quality and yield of solids. Fruit from trees planted at DR/HD contained 5\% more soluble solids than fruit from the SR/ LD configuration in both seasons (Table 6). In addition, fruit acidity was $13 \%$ and $6 \%$ greater under DR/HD than other treatments in 2018-19 and 2019-20, respectively. In 2018-19, the acidic nature of the juice induced $7 \%$ lower ratio in the DR/HD planting.
In both seasons, fruit from the DR/HD configuration produced $130 \%$ to $200 \%$ greater yield of solids than other treatments (Table 6). In 2018-19, the CRF blend did not affect fruit quality (Table 6); however, in 2019-20 CRF 1 induced 10\% higher soluble solids, $7 \%$ higher ratio, and $86 \%$ greater yield of solids than CRF 2. In 2019-20, an interaction was observed between CRF blends and planting density $(P=0.0179)$ whereby CRF 1 use in $\mathrm{DR} / \mathrm{HD}$ planting produced higher yield of solids than other treatments (Fig. 4). In 2019-20, fruit increased acidity with an increase in the FAM rate applied (Table 6, $P=$ 0.0101).

Plant physiology. Photosynthetic rates under DR/HD were $12 \%$ and $21 \%$ lower than under SR/LD and SR/HD, respectively. The $\mathrm{SR} / \mathrm{HD}$ resulted in $16 \%$ higher $g_{\mathrm{S}}$ than DR/ HD planting. Use of CRF 1 increased photosynthesis $(17 \%)$, intercellular $\mathrm{CO}_{2}(10 \%), g_{\mathrm{S}}$ (45\%), and transpiration (46\%) compared with CRF 2 (Table 7); however, FAM application reduced the assimilation rate, intercellular $\mathrm{CO}_{2}$, and $g_{\mathrm{S}}$. A significant interaction of intercellular $\mathrm{CO}_{2}$ was observed between tree planting density and CRF blends. The CRF 1 resulted in better intercellular $\mathrm{CO}_{2}$ in all the planting densities (Fig. 5).

Leaf nutrient concentration. Leaf calcium (Ca) and $\mathrm{N}$ concentrations ranged from 3.0 to 4.9 and 2.5 to $2.7 \mathrm{~g} \cdot \mathrm{kg}^{-1}$ under all treatments, respectively (Table 8 ), which are within the optimal ranges defined by Koo et al. (1984). In addition, leaf $\mathrm{P}, \mathrm{Fe}$, and $\mathrm{Mg}$ concentration decreased over time in all the treatments. Leaf copper $(\mathrm{Cu})$ concentration was excessively high $\left(>20 \mathrm{mg} \cdot \mathrm{kg}^{-1}\right)$ under all treatments due to frequent application of fungicides containing $\mathrm{Cu}$ to control citrus 
canker disease (Xanthomonas axonopodis pv. citri). In 2018-19, leaf Mn concentration was optimal (25-100 $\left.\mathrm{mg} \cdot \mathrm{kg}^{-1}\right)$ for all treatments, except 6 times foliar spray of recommended rate, where it exceeded the optimum range. In 2018-19, leaf sulfur (S) concentration showed an interaction between planting density and CRF blends, in which CRF 1 showed higher leaf S concentration (Fig. 6). It could be due to the higher amount of S-coated fertilizer present in CRF 1 blend. In 2019 20 , leaf $\mathrm{B}, \mathrm{Mn}$, and $\mathrm{Zn}$ concentration showed an interaction between planting and $\mathrm{CRF}$ blends (Fig. 7).

Soil nutrient concentrations and soil $\mathrm{pH}$. There was only a planting density effect on soil nutrient concentrations in 2019-20 (Tables 9 and 10). DR/HD plots had higher soil concentrations of $\mathrm{K}, \mathrm{Ca}, \mathrm{Mg}, \mathrm{S}$, and $\mathrm{B}$, but lower $\mathrm{P}$ concentration in comparison to

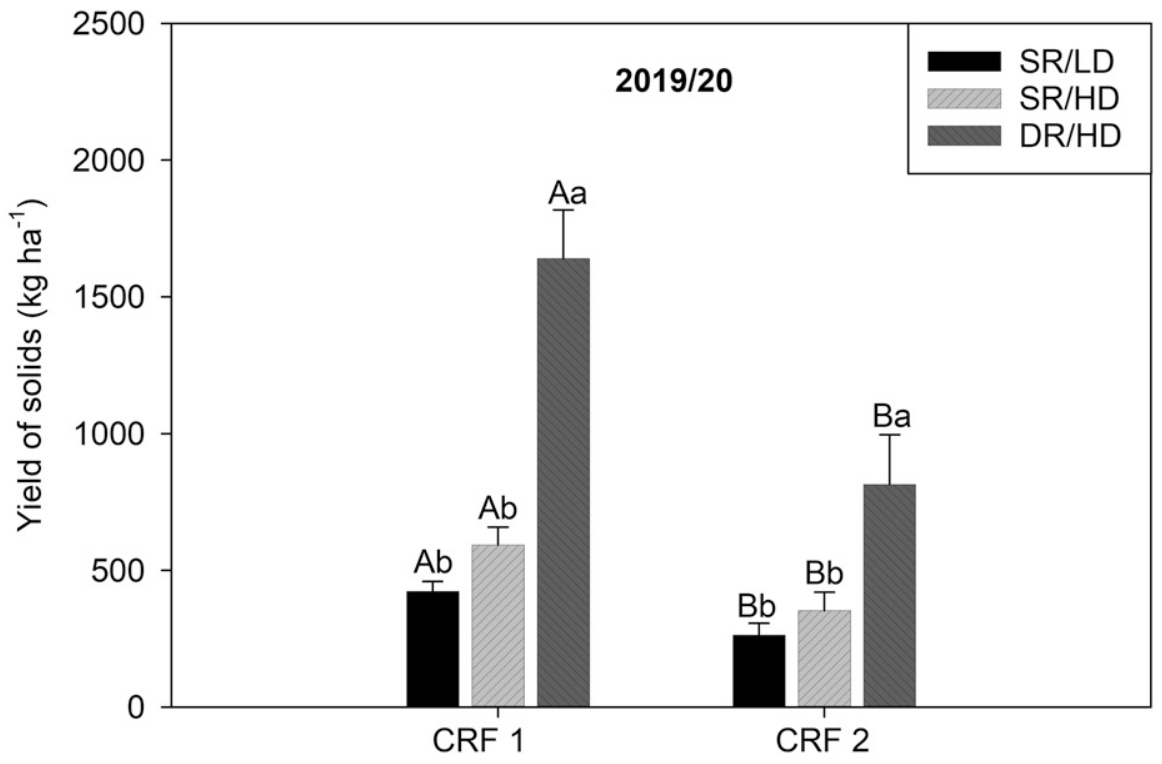

Fig. 4. Yield of solids under two controlled-release fertilizers (CRF) blends [CRF 1 (12N-1.31P-7.47K with 2.5 times micronutrients and 2 times $\mathrm{Mg})$ and $\mathrm{CRF} 2(16 \mathrm{~N}-1.31 \mathrm{P}-16.6 \mathrm{~K})]$; and three planting densities [single-row low-density (SR/LD, 300 trees per ha), single-row high-density (SR/HD, 440 trees per ha), and double-row highdensity staggered in diamond setting (DR/HD, 975 trees per ha)]. Means \pm SE followed by different letters (uppercase compare CRF and lowercase compare $\mathrm{PD}$ ) are significantly different by Tukey's test at $P<0.05$. other treatments. Higher availability of nutrients in soil sampled from high-density plantings could be due to less uptake by trees due to reduced root volume from HLB damage.

The CRF blends resulted in changes in soil $\mathrm{pH}$ and nutrient availability (Tables 9 and 10). In 2018-19, CRF 2 (CRF blend with lower micronutrient rates) increased soil $\mathrm{pH}$ by $6 \%$, soil $\mathrm{B}$ concentration by $100 \%$, and decreased $\mathrm{Mn}$ concentration by $55 \%$. In 2019-20, the use of CRF 2 increased soil pH by $12 \%, \mathrm{~B}, \mathrm{Mg}$, and $\mathrm{Zn}$ concentrations by $25 \%, 13 \%$, and $19 \%$, respectively, whereas $\mathrm{S}$ concentrations fell by $42 \%$ compared with use of CRF 1. Interestingly, despite the lower $\mathrm{B}$ concentration in CRF 2, B availability in soil was higher relative to CRF 1 (Table 11). Both CRF blends resulted in optimum soil $\mathrm{pH}$ for most of the nutrients as suggested by Morgan and Kadyampakeni (2020). Using the soil test interpretation outlined by Morgan and Kadyampakeni (2020), the Mehlich 3 acid extraction showed a medium to high level of soil $\mathrm{P}$ concentrations, whereas $\mathrm{Mg}$ concentrations were low in 2018-19 but medium to high in 2019-20. In 2019-20, FAM only affected soil Mn and Zn concentrations (Table 10), which was probably caused by the spray solution reaching the soil. Boaretto et al. (2002) also observed a similar result with a foliar spray of $\mathrm{Zn}$ in orange trees.

\section{Discussion}

CLas infection. Our study showed no treatment effect on $\mathrm{Ct}$ value, which differs from earlier work by Zhang et al. (2016) that showed $\mathrm{Zn}$ application on 2-year-old

Table 5. Fruit size and total number of fruit as a function of controlled-release fertilizer (CRF), planting density (PD), and foliar-applied micronutrients (FAM).

\begin{tabular}{|c|c|c|c|c|c|c|c|c|}
\hline \multirow[b]{2}{*}{ Treatments } & \multicolumn{2}{|c|}{$\begin{array}{c}\text { Small size fruit } \\
\text { (less than } 100 \mathrm{~mm} \text { ) }\end{array}$} & \multicolumn{2}{|c|}{$\begin{array}{l}\text { Medium size fruit } \\
(100 \mathrm{~mm}-117 \mathrm{~mm})\end{array}$} & \multicolumn{2}{|c|}{$\begin{array}{l}\text { Large size fruit } \\
\text { (above } 100 \mathrm{~mm} \text { ) }\end{array}$} & \multicolumn{2}{|c|}{ Total no. of fruit } \\
\hline & $2018-19$ & $2019-20$ & $2018-19$ & $2019-20$ & $2018-19$ & $2019-20$ & $2018-19$ & $2019-20$ \\
\hline \multicolumn{9}{|l|}{$\overline{\mathrm{CRF}^{\mathrm{z}}}$} \\
\hline CRF 1 & $18.64 \pm 0.98^{w}$ & $41.74 \pm 1.93$ & $6.04 \pm 0.41$ & $14.36 \pm 1.28 b$ & $0.46 \pm 0.08$ & $0.82 \pm 0.12$ & $25.15 \pm 1.25$ & $56.93 \pm 2.67 b$ \\
\hline CRF 2 & $18.12 \pm 0.85$ & $46.11 \pm 1.63$ & $6.42 \pm 0.37$ & $18.23 \pm 1.08 \mathrm{a}$ & $0.42 \pm 0.06$ & $0.72 \pm 0.08$ & $24.94 \pm 1.04$ & $65.06 \pm 2.17 \mathrm{a}$ \\
\hline \multicolumn{9}{|l|}{$\mathrm{PD}^{\mathrm{y}}$} \\
\hline SR/LD & $18.23 \pm 1.12$ & $40.35 \pm 1.87 b$ & $6.58 \pm 0.54$ & $20.73 \pm 1.64 \mathrm{a}$ & $0.40 \pm 0.10$ & $1.02 \pm 0.14 \mathrm{a}$ & $25.21 \pm 1.46$ & $62.1 \pm 2.83 \mathrm{a}$ \\
\hline $\mathrm{SR} / \mathrm{HD}$ & $19.63 \pm 1.21$ & $50.93 \pm 2.49 \mathrm{a}$ & $6.70 \pm 0.47$ & $19.43 \pm 1.53 \mathrm{a}$ & $0.46 \pm 0.08$ & $0.98 \pm 0.16 \mathrm{a}$ & $26.79 \pm 1.47$ & $71.34 \pm 3.35 \mathrm{a}$ \\
\hline $\mathrm{DR} / \mathrm{HD}$ & $17.27 \pm 1.03$ & $40.51 \pm 2.05 b$ & $5.41 \pm 0.40$ & $8.73 \pm 0.85 b$ & $0.46 \pm 0.07$ & $0.30 \pm 0.06 \mathrm{~b}$ & $23.13 \pm 1.28$ & $49.55 \pm 2.46 b$ \\
\hline \multicolumn{9}{|l|}{ FAM $^{x}$} \\
\hline $0.0 \times$ & $21.72 \pm 1.57 \mathrm{a}$ & $48.74 \pm 2.75 \mathrm{a}$ & $6.82 \pm 0.58$ & $22.10 \pm 2.31 \mathrm{a}$ & $0.43 \pm 0.09$ & $0.84 \pm 0.14$ & $28.97 \pm 1.89 \mathrm{a}$ & $71.69 \pm 4.16 \mathrm{a}$ \\
\hline $1.5 \times$ & $18.93 \pm 1.19 \mathrm{ab}$ & $47.53 \pm 2.90 \mathrm{a}$ & $6.39 \pm 0.50$ & $14.47 \pm 1.60 \mathrm{~b}$ & $0.48 \pm 0.08$ & $0.65 \pm 0.17$ & $25.79 \pm 1.48 \mathrm{ab}$ & $62.65 \pm 3.56 \mathrm{a}$ \\
\hline $3.0 \times$ & $17.97 \pm 1.26 \mathrm{ab}$ & $44.75 \pm 2.31 \mathrm{a}$ & $6.77 \pm 0.62$ & $15.03 \pm 1.37 \mathrm{~b}$ & $0.57 \pm 0.13$ & $0.67 \pm 0.12$ & $25.31 \pm 1.65 \mathrm{ab}$ & $60.45 \pm 3.14 \mathrm{ab}$ \\
\hline $6.0 \times$ & $14.90 \pm 1.04 \mathrm{~b}$ & $34.70 \pm 1.80 \mathrm{~b}$ & $4.93 \pm 0.48$ & $13.58 \pm 1.12 \mathrm{~b}$ & $0.28 \pm 0.07$ & $0.92 \pm 0.16$ & $20.1 \pm 1.32 \mathrm{~b}$ & $49.20 \pm 2.42 b$ \\
\hline Sources of variation & \multicolumn{8}{|c|}{$P$ value } \\
\hline CRF & NS & NS & NS & $*$ & NS & NS & NS & $*$ \\
\hline PD & NS & $* * *$ & NS & $* * *$ & NS & $* * *$ & NS & $* * *$ \\
\hline $\mathrm{CRF}^{*} \mathrm{PD}$ & NS & NS & NS & NS & NS & NS & NS & NS \\
\hline FAM & $* *$ & $* * *$ & NS & $* * *$ & NS & NS & $* *$ & $* * *$ \\
\hline CRF*FAM & $*$ & NS & NS & NS & NS & NS & NS & NS \\
\hline PD*FAM & NS & NS & NS & $*$ & NS & NS & NS & NS \\
\hline CRF*PD*FAM & NS & $*$ & NS & NS & NS & NS & NS & NS \\
\hline
\end{tabular}

${ }^{\mathrm{z}} \mathrm{In} 2018-19$, CRF $1=12 \mathrm{~N}-1.31 \mathrm{P}-7.47 \mathrm{~K}$ with higher micronutrient content; and CRF $2=16 \mathrm{~N}-1.31 \mathrm{P}-16.6 \mathrm{~K}$. In $2019-20$, CRF $1=12 \mathrm{~N}-1.31 \mathrm{P}-11.62 \mathrm{~K}$ with 2 times $\mathrm{Mg}$ and 2.5 times micronutrients; and $\mathrm{CRF} 2=12 \mathrm{~N}-1.31 \mathrm{P}-11.62 \mathrm{~K}$.

${ }^{y} \mathrm{SR} / \mathrm{LD}=$ single-row low-density (300 trees per ha). $\mathrm{SR} / \mathrm{HD}=$ single-row high-density (440 trees per ha). $\mathrm{DR} / \mathrm{HD}=$ double-row high-density $(975$ trees per ha).

${ }^{\mathrm{x}}$ Foliar applied micronutrients using the recommended rates of $\mathrm{B}, \mathrm{Mn}$, and $\mathrm{Zn}$ per year.

${ }^{\mathrm{w}}$ Mean \pm SE followed by different lowercase letters are significantly different at $P<0.05$ by Tukey's test.

NS, ${ }^{*}, * *, * * *$ Nonsignificant or significant at $P<0.05,0.01$, or 0.001 , respectively. 
Table 6. Soluble solids content, acidity, ratio, and yield of solids as a function of controlled-release fertilizer (CRF), planting density (PD), and foliar-applied micronutrients (FAM).

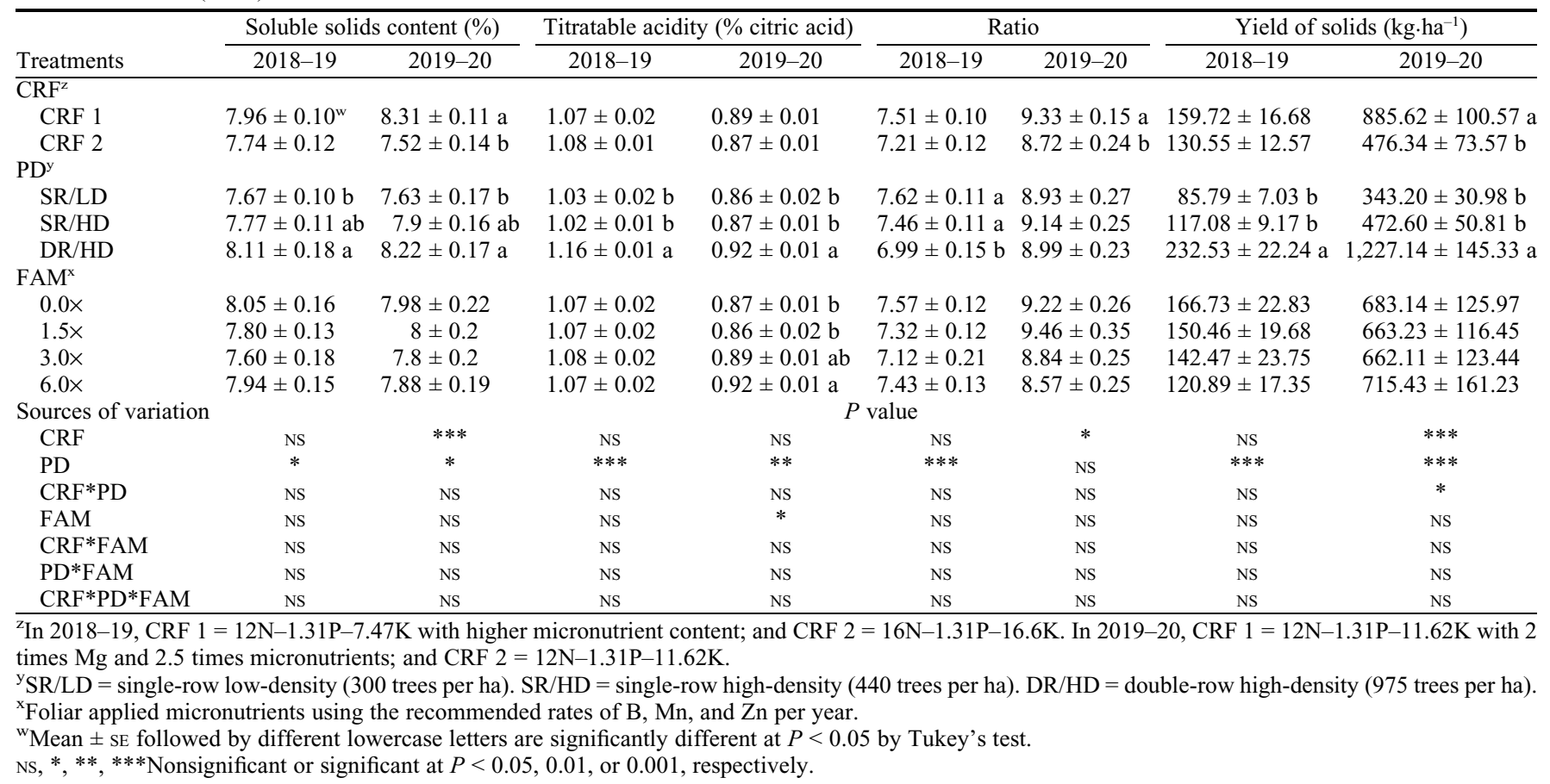

Table 7. Assimilation rate, intercellular $\mathrm{CO}_{2}$, stomatal conductance $\left(g_{\mathrm{S}}\right)$, and transpiration rate as a function of controlled-release fertilizer (CRF), planting density (PD), and foliar-applied micronutrients (FAM).

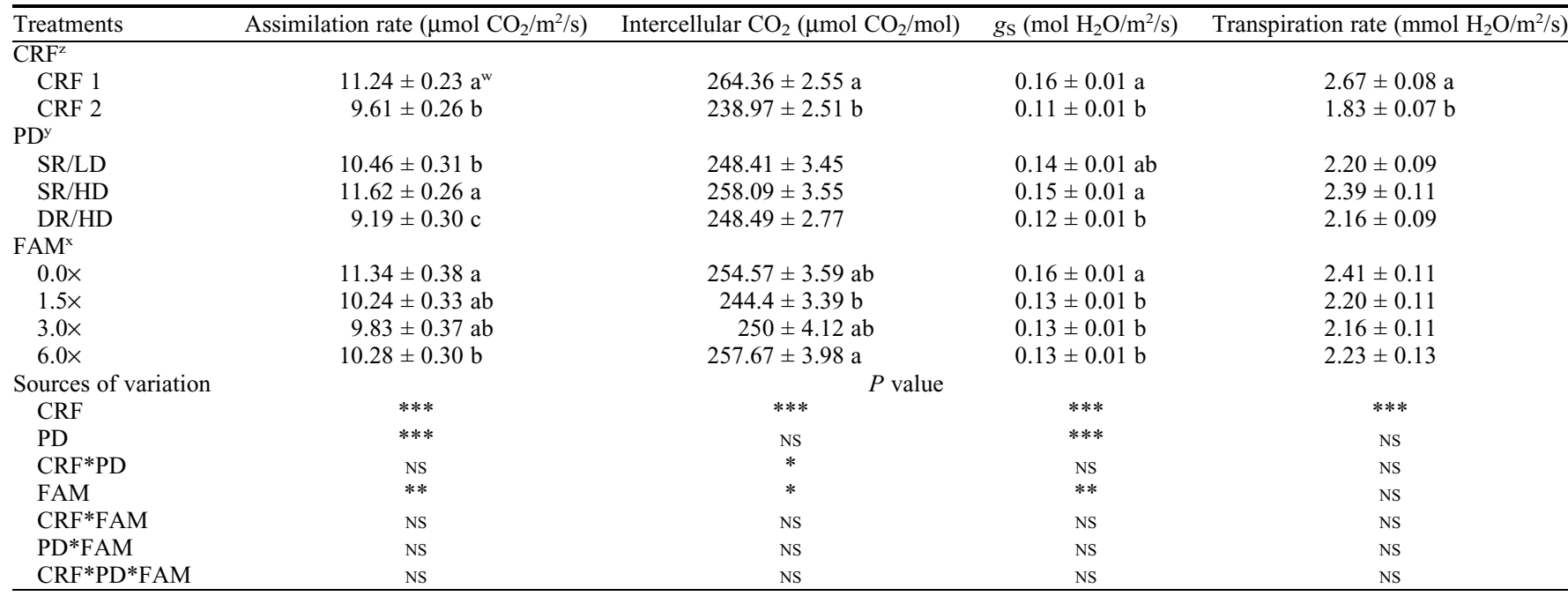

${ }^{\mathrm{z}}$ In 2018-19, CRF $1=12 \mathrm{~N}-1.31 \mathrm{P}-7.47 \mathrm{~K}$ with higher micronutrient content; and CRF $2=16 \mathrm{~N}-1.31 \mathrm{P}-16.6 \mathrm{~K}$. In 2019-20, CRF $1=12 \mathrm{~N}-1.31 \mathrm{P}-11.62 \mathrm{~K}$ with 2 times $\mathrm{Mg}$ and 2.5 times micronutrients; and CRF $2=12 \mathrm{~N}-1.31 \mathrm{P}-11.62 \mathrm{~K}$.

${ }^{\mathrm{y}} \mathrm{SR} / \mathrm{LD}=$ single-row low-density (300 trees per ha). SR/HD = single-row high-density (440 trees per ha). DR/HD = double-row high-density $(975$ trees per ha).

${ }^{\mathrm{x}}$ Foliar applied micronutrients using the recommended rates of $\mathrm{B}, \mathrm{Mn}$, and $\mathrm{Zn}$ per year.

${ }^{\mathrm{w}}$ Mean \pm SE followed by different lowercase letters are significantly different at $P<0.05$ by Tukey's test.

NS, $*, * *, * * *$ Nonsignificant or significant at $P<0.05,0.01$, or 0.001 , respectively.

grapefruit seedlings lowered $\mathrm{Ct}$ values. The absence of a soil-applied micronutrient or $\mathrm{Mg}$ effect on $\mathrm{Ct}$ values may have been due to the relatively short length of our study. As with soil-applied nutrients, we found that FAMs did not affect $\mathrm{Ct}$ values. Gottwald et al. (2012) similarly observed no visual differences or disease expression in HLBaffected 'Valencia' trees treated with different micronutrient applications. A longer trial period may be needed to observe dif- ferences in disease expression (Shen et al., 2013) and as was demonstrated in sweet orange by Morgan et al. (2016) in their 5year study. Stansly et al. (2014) noted that nutritional treatments can improve tree growth, which increases opportunities for psyllid feeding and ultimately causes higher bacterial titer or lower $\mathrm{Ct}$ value. These results suggest that FAMs may be counterproductive unless psyllid control measures are effective.
Tree growth. The decrease in trunk diameter and canopy volume as planting density increased was expected because high-density planting increases competition for water, nutrients, and solar radiation. As with CRF 1 (blend with higher nutrient application), Morgan and Kadyampakeni (2020) indicated the higher nutrient application results in greater tree growth with the expense of yield, as seen in reduced number of fruit in 2019-20 in our study (Table 4). FAM did not affect 


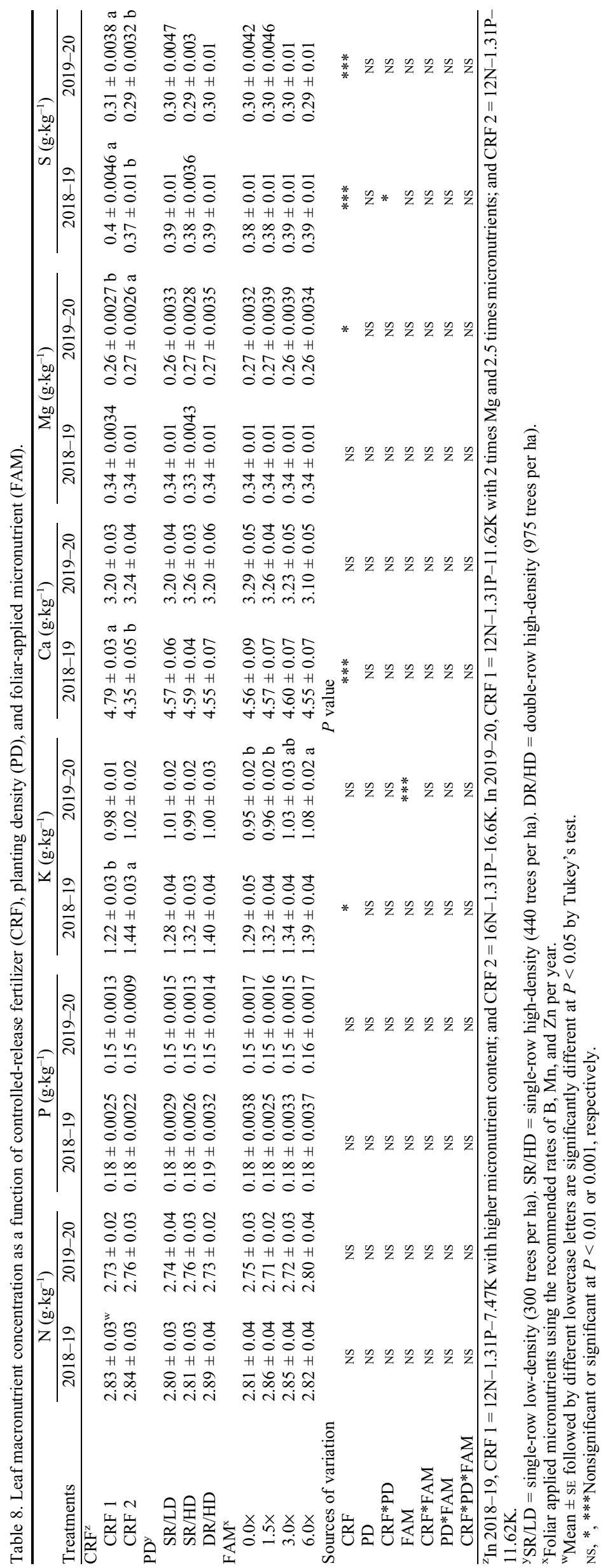




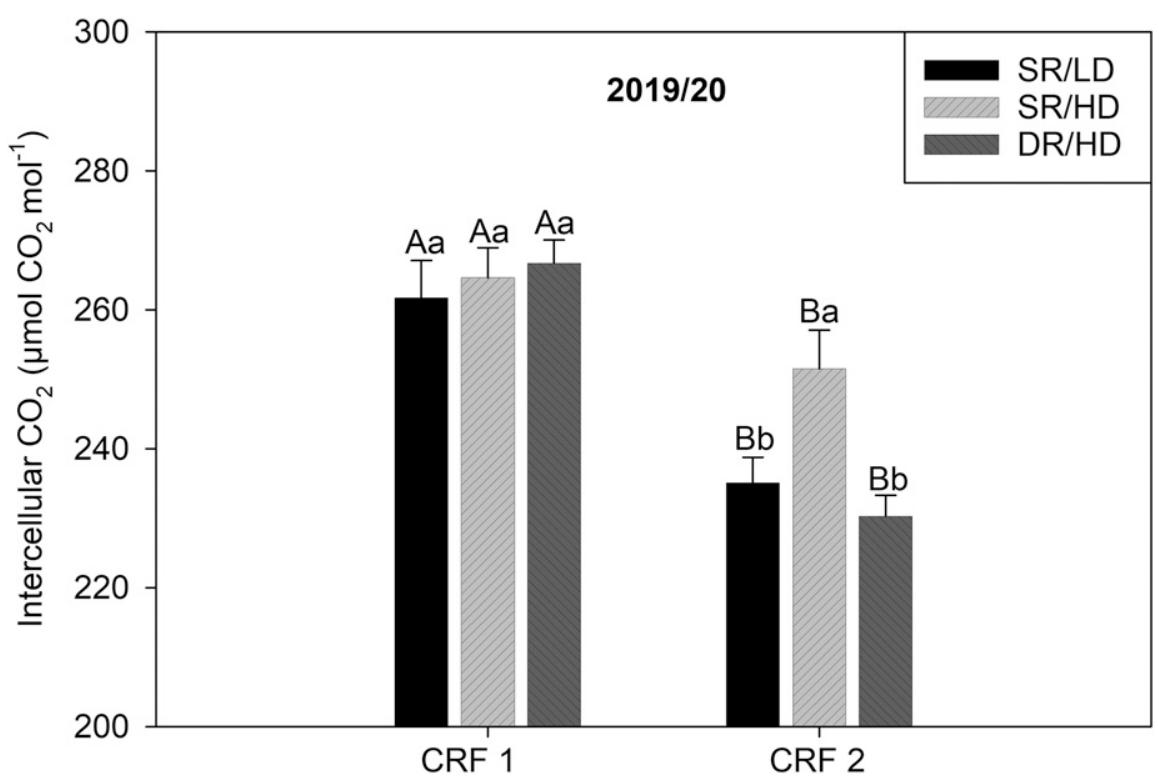

Fig. 5. Intercellular $\mathrm{CO}_{2}$ under two controlled-release fertilizer (CRF) blends [CRF $1(12 \mathrm{~N}-1.31 \mathrm{P}-7.47 \mathrm{~K}$ with 2.5 times micronutrients and 2 times $\mathrm{Mg}$ ) and $\mathrm{CRF} 2(16 \mathrm{~N}-1.31 \mathrm{P}-16.6 \mathrm{~K})]$; and three planting density (PD) [single-row low-density (SR/LD, 300 trees per ha), single-row high-density (SR/HD, 440 trees per ha), and double-row high-density staggered in diamond setting (DR/HD, 975 trees per ha)]. Means \pm SE followed by different letters (uppercase compare CRF and lowercase compare PD) are significantly different by Tukey's test at $P<0.05$.

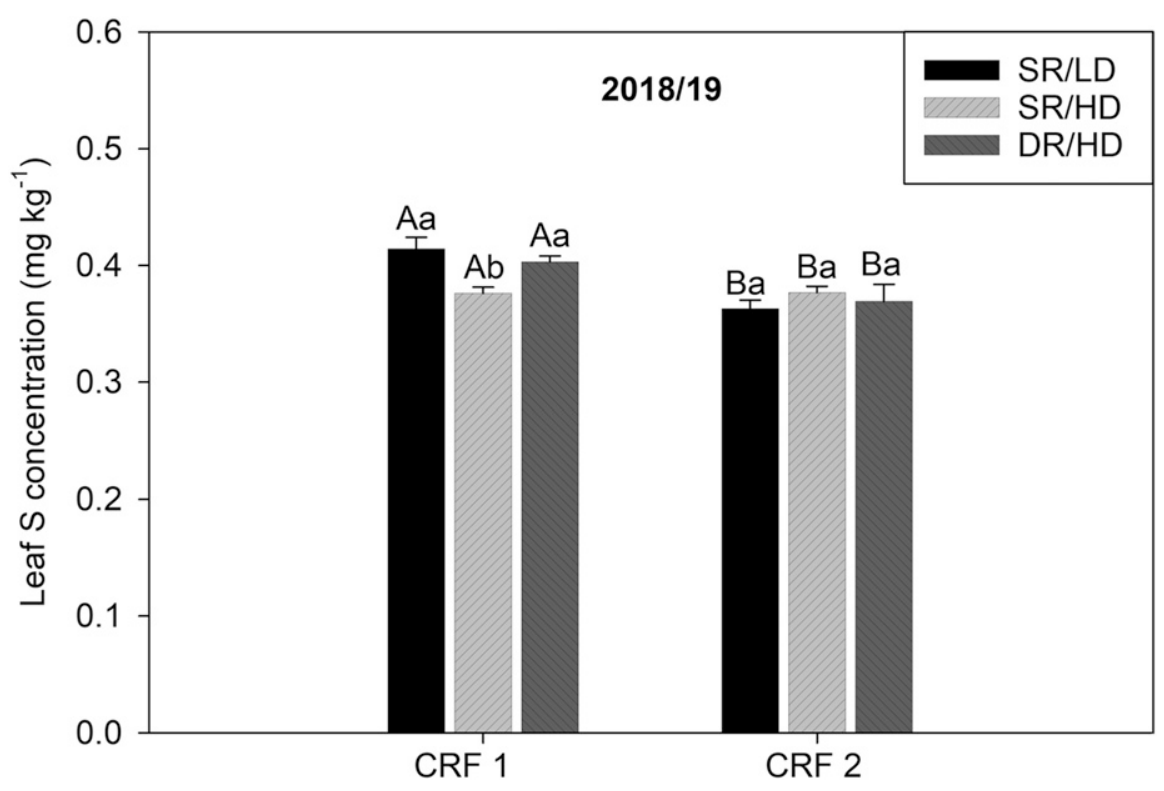

Fig. 6. Leaf S concentration under two controlled-release fertilizers (CRF) blends [CRF $1(12 \mathrm{~N}-1.31 \mathrm{P}-$ $7.47 \mathrm{~K}$ with higher amount of micronutrient) and CRF $2(16 \mathrm{~N}-1.31 \mathrm{P}-16.6 \mathrm{~K})]$; and three planting density (PD) [single-row low-density (SR/LD, 300 trees per ha), single-row high-density (SR/HD, 440 trees per ha), and double-row high-density staggered in diamond setting (DR/HD, 975 trees per ha)]. Means $\pm \mathrm{SE}$ followed by different letters (uppercase compare CRF and lowercase compare PD) are significantly different by Tukey's test at $P<0.05$.

canopy volume in HLB-affected orange trees as in Rouse et al. (2017). A long-term study could manifest differences in canopy volume with the application of foliar treatments, such as in Morgan et al. (2016).

Fruit yield and fruit size. High-density planting with UF/IFAS-recommended nutrient application increased the fruit yield but reduced the total number of fruit. The higher soil nutrient application tended to increase canopy growth at the expense of fruit yield. In addition, in our study, FAM showed negative effect on fruit yield and fruit size (Table 5). The effect of foliar nutrient application on citrus fruit yield is a topic of controversy. Several studies have shown that foliar application alone or in combination with plant hormones and insecticides can increase fruit yields in HLB-affected orchards (Al-Obeed et al., 2018; Morgan et al., 2016; Stansly et al., 2014). However, other studies indicated foliar nutrient application is not effective for enhancing fruit yield and quality (Boaretto et al., 1997, 2002; Gottwald et al., 2012). In our study, the negative correlation between foliar nutrient application and fruit yield may have been due in part to vegetative growth, as was also reported in sweet orange by Morgan et al. (2016).

Fruit quality and yield of solids. The fruit quality was affected by planting density, as in Phuyal et al. (2020), suggesting that highdensity planting results in the accumulation of more sugars with acidic juice. As with CRF, we obtained greater soluble solids from higher micronutrient application. With all the treatments, the ratio was higher than the standard ratio outlined for grapefruit grade B which is 7:1 (U.S. Department of Agriculture, 2012). In our study, we observed an increase in fruit acidity with FAM application possibly due to increase in leaf $\mathrm{K}$ and $\mathrm{Zn}$ concentration with the application of higher rates of micronutrients, like Nasir et al. (2016) observed in mandarin.

Plant physiology. Because photosynthesis is a physiological process requiring sunlight, high-density planting could have impaired photosynthetic rates as a result of shading.

Goldman (2010) noted that micronutrients are important for plant photosynthesis, particularly $\mathrm{Mn}$ for chlorophyll formation, and $\mathrm{Zn}$ as an important cofactor for enzyme carbonic anhydrase. To our knowledge, the effect of soil elevated micronutrient application on grapefruit plant physiology under field conditions has never been tested before. We observed elevated soil micronutrient concentrations can improve plant photosynthesis, thereby enhancing canopy growth. Net photosynthesis and $g_{\mathrm{S}}$ were negatively affected by increasing FAM rates, contradicting earlier findings by Ilyas et al. (2015) that revealed an increase in net photosynthetic rate, $g_{\mathrm{S}}$, and transpiration with foliar application of $\mathrm{B}, \mathrm{Cu}$, and $\mathrm{Zn}$. Our findings show that FAM may have caused plant stress or excessive growth due to luxurious nutrient supply (Table 9). Morgan and Connolly (2013) suggested that excessive micronutrient accumulation can damage plant cells by generating reactive oxygen species.

Leaf nutrient concentration. There was a general trend showing that use of CRF 1 resulted in similar or higher leaf micronutrient concentrations than using CRF 2 for both seasons. This outcome was expected because CRF 1 contained higher amounts of micronutrients than CRF 2. As with CRF, FAM application also affected foliar micronutrient concentrations. There was a positive correlation between FAM and leaf B, Mn, and $\mathrm{Zn}$ concentration in 2018-19. In 201920 , this trend was limited to $\mathrm{Mn}$ and $\mathrm{Zn}$. There was also an increase in $\mathrm{K}$ and decrease in $\mathrm{Cu}$ concentrations, respectively. $\mathrm{B}, \mathrm{Zn}$, or their combination may have facilitated $\mathrm{K}$ uptake, as was previously noted by Mengel and Kirkby (1980). The decrease in $\mathrm{Cu}$ concentration with increase in foliar rate was 

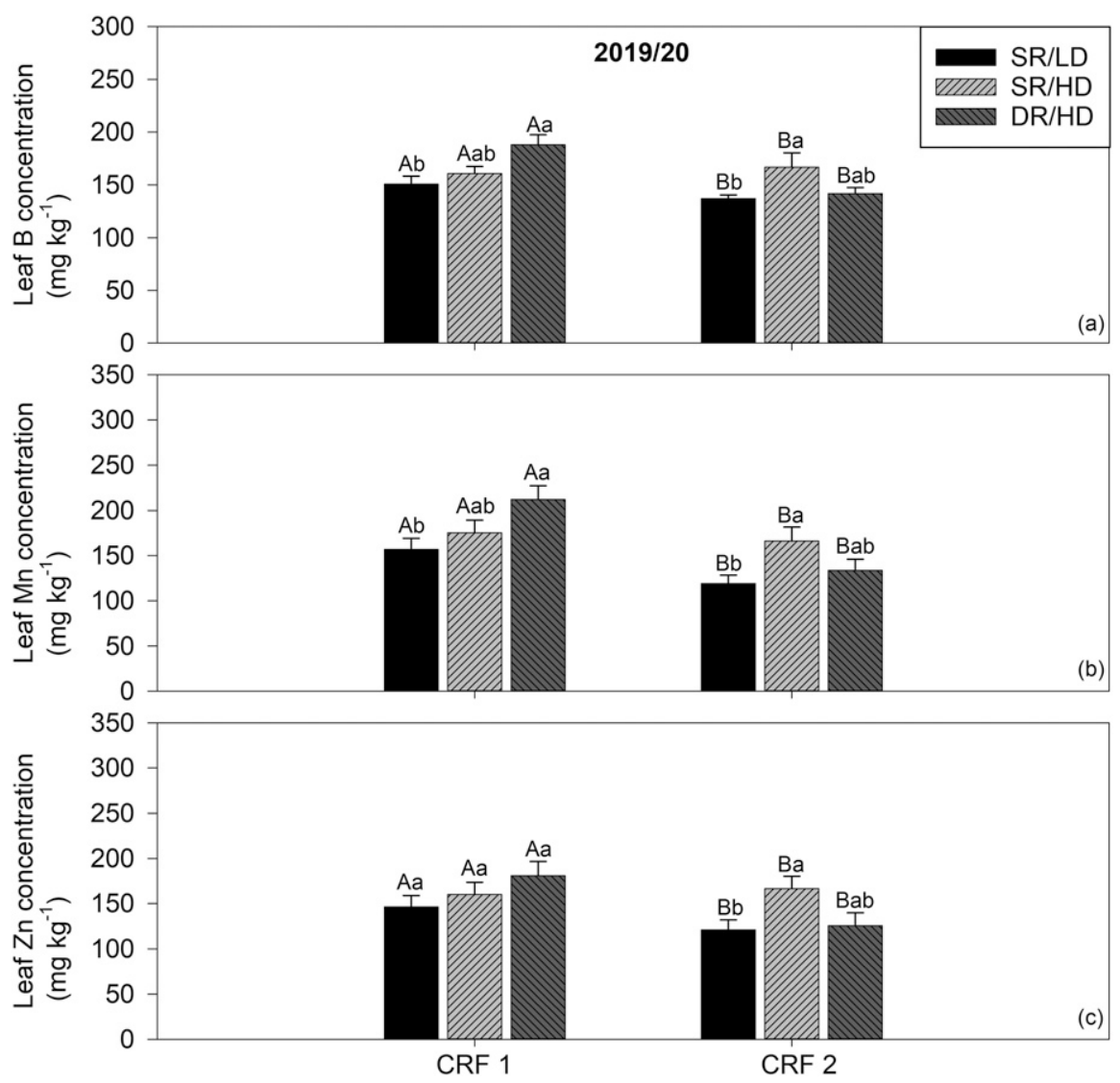

Fig. 7. The concentration of $\mathrm{B}(\mathbf{A}), \operatorname{Mn}(\mathbf{B})$, and $\mathrm{Zn}(\mathbf{C})$ in the leaves under two controlled-release fertilizers (CRF) blends [CRF $1(12 \mathrm{~N}-1.31 \mathrm{P}-7.47 \mathrm{~K}$ with 2.5 times micronutrients and 2 times $\mathrm{Mg}$ ) and CRF 2 $(16 \mathrm{~N}-1.31 \mathrm{P}-16.6 \mathrm{~K})$ ]; and three planting density $(\mathrm{PD})$ [single-row low-density (SR/LD, 300 trees per ha), single-row high-density (SR/HD, 440 trees per ha), and double-row high-density staggered in diamond setting (DR/HD, 975 trees per ha)]. Means \pm SE followed by different letters (uppercase compares CRF and lowercase compare PD) are significantly different by Tukey's test at $P<0.05$.

possibly because of an antagonistic effect of $\mathrm{Zn}$. Studies have shown the antagonisms of $\mathrm{Zn}$ on $\mathrm{Cu}$ nutrition in wheat (Triticum aestivum) and rice (Oryza sativa) (Chaudhry et al., 1973; Imtiaz et al., 2003).

Soil nutrient concentrations and soil $\mathrm{pH}$. In our study, soil samples from CRF 2 treatment showed higher $\mathrm{B}$ concentration in the soil even though we applied less B than CRF 1. Goldberg et al. (2000) reported that soil B availability depends on several factors, including soil texture, moisture, temperature, and oxide content along with soil $\mathrm{pH}$ because low pH favors B uptake. Zhu et al. (2007) reported that the $\mathrm{B}$ concentration in soils is generally related to the amount of B taken up by plants. In our study, CRF 1 decreased soil $\mathrm{pH}$ which could have facilitated B uptake by the trees. In addition, the increase in $\mathrm{S}$ content with CRF 1 is probably from the higher application of S-coated fertilizer. The application of higher amount of $\mathrm{Mg}$ via CRF 1 shows $11 \%$ lower $\mathrm{Mg}$ concentration in soil (Table 10) potentially because of the interaction between nutrient and soil $\mathrm{pH}$ as $\mathrm{Mg}$ is highly mobile element in soil and shows its maximum availability in the soil $\mathrm{pH}$ range of 7 to 8 (Gransee and Führs, 2013; Truog, 1947). Prior studies showed that Mg availability reduces drastically in the soil with a

small increase in soil pH (Hailes et al., 1997; Sumner et al., 1978). In our study, CRF 1 resulted in a low soil $\mathrm{pH}$ (5.63), which was $11 \%$ lower than CRF 2. The lower $\mathrm{pH}$ in CRF 1 could have decreased the $\mathrm{Mg}$ availability in the soil.

\section{Conclusions}

The planting density did not affect $\mathrm{Ct}$ value. High-density planting resulted in smaller trunk diameter and canopy volume. Despite lower yield per tree in 2019-20, high-density planting induced the greatest fruit yields on an area basis. Also, fruit produced under high-density plantings had higher soluble solids and was more acidic. Higher micronutrient application did not affect fruit yield but did improve tree physiological parameters and canopy volume. FAM did not affect HLB incidence, tree growth, or fruit quality. However, fruit yield and physiological parameters decreased as FAM increased. Over the 2-year period, our study showed that excessive supplemental nutrient application may increase vegetative growth at the cost of reduced yield and may not be beneficial for grapefruit trees affected by HLB, whereas high-density plantings can improve yield. Moving forward, manage- ment costs, along with long-term yield response to higher-density plantings should be determined before recommendations can be made to growers. In addition, information is needed on nutritional treatment effects on other HLB-tolerant rootstocks.

\section{Literature Cited}

Albrecht, U. and K.D. Bowman. 2011. Tolerance of the trifoliate citrus hybrid US-897 (Citrus reticulata Blanco $\times$ Poncirus trifoliata $\mathrm{L}$. Raf.) to Huanglongbing. HortScience 46:1622.

Al-Obeed, R.S., M.A.A. Ahmed, H.A. Kassem, and A.M. Al-Saif. 2018. Improvement of "Kinnow" mandarin fruit productivity and quality by urea, boron, and zinc foliar spray. J. Plant Nutr. 41:609-618.

Boaretto, A.E., C.S. Tiritan, and T. Muraoka. 1997. Effects of foliar applications of boron on citrus fruit and on foliage and soil boron concentration, p. 121-123. In: R.W. Bell and B. Rerkasem (eds.). Boron in soils and plants. Springer, Dordrecht.

Boaretto, A.E., R.M. Boaretto, T. Muraoka, V.F Nascimento Filho, C.S. Tiritan, and F.A.A. Mourão Filho. 2002. Foliar micronutrient application effects on citrus fruit yield, soil, and leaf $\mathrm{Zn}$ concentrations and $65 \mathrm{Zn}$ mobilization within the plant. Acta Hort. 594: 203-209.

Chaudhry, F.M., M. Sharif, A. Latif, and R.H. Qureshi. 1973. Zinc-copper antagonism in the nutrition of rice (Oryza sativa). Plant Soil 38:573-580.

Dalal, R.P.S., A.K. Sangwan, B.S. Beniwal, and S. Sharma. 2013. Effect of planting density on canopy parameter, yield and water use efficiency of Kinnow mandarin. Indian J. Hort. 70:587-590

Etxeberria, E., P. Gonzalez, D. Achor, and G. Albrigo. 2009. Anatomical distribution of abnormally high levels of starch in HLB-affected Valencia orange trees. Physiol. Mol. Plant Pathol. 74:76-83.
Ferrarezi, R.S., J.A. Qureshi, A.L. Wright, M.A. Ritenour, and N.P. Macan. 2019. Citrus production under screen as a strategy to protect grapefruit trees from Huanglongbing disease. Frontiers in Plant Sci. 10:1598.

Gerendás, J. and H. Führs. 2013. The significance of magnesium for crop quality. Plant Soil 368:101-128.

Goldberg, S., S.M. Lesch, and D.L. Suarez. 2000. Predicting boron adsorption by soils using soil chemical parameters in the constant capacitance model. Soil Sci. Soc. Amer. J. 64:13561363.

Goldman, C.R. 2010. Micronutrient elements (Co, $\mathrm{Mo}, \mathrm{Mn}, \mathrm{Zn}, \mathrm{Cu}$ ), p. 378-382. In: Biogeochemistry of inland waters. Academic Press, San Diego, CA

Gonzalez, P., J. Reyes-De-Corcuera, and E. Etxeberria. 2012. Characterization of leaf starch from HLBaffected and unaffected-girdled citrus trees. Physiol. Mol. Plant Pathol. 79:71-78.

Gottwald, T.R., J.H. Graham, M.S. Irey, T.G. McCollum, and B.W. Wood. 2012. Inconsequential effect of nutritional treatments on Huanglongbing control, fruit quality, bacterial titer, and disease progress. Crop Prot. 36:7382.

Gransee, A. and H. Führs. 2013. Magnesium mobility in soils as a challenge for soil and plant analysis, magnesium fertilization and root uptake under adverse growth conditions. Plant Soil 368:5-21. 


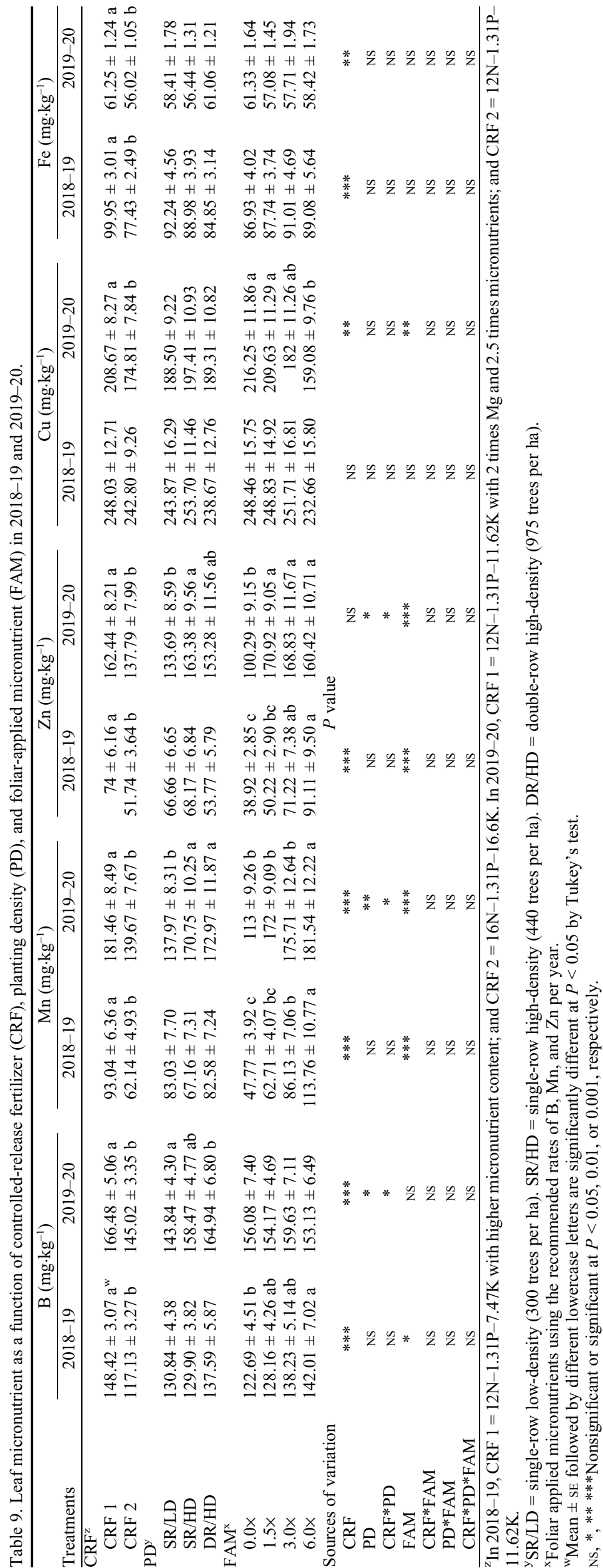

1430
Hailes, K.J., R.L. Aitken, and N.W. Menzies. 1997. Magnesium in tropical and subtropical soils from north-eastern Australia. II. Response by glasshouse-grown maize to applied magnesium. Austral. J. Soil Res. 35:629-642.

Huber, D.M. and J.B. Jones. 2013. The role of magnesium in plant disease. Plant Soil 368:7385.

Ibrahim, M., N. Ahmad, S.A. Anwar, and T. Majeed. 2007. Effect of micronutrients on citrus fruit yield growing on calcareous soils, $\mathrm{p}$. 179-182. In: F. Xu, H.E. Goldbach, P.H. Brown, et al. Advances in plant and animal boron nutrition. Springer, Dordrecht, The Netherlands.

Iglesias, D.J., I. Lliso, F.R. Tadeo, and M. Talon. 2002. Regulation of photosynthesis through source: Sink imbalance in citrus is mediated by carbohydrate content in leaves. Physiol. Plant. 116:563-572.

Ilyas, A., M.Y. Ashraf, M. Hussain, M. Ashraf, R. Ahmed, and A. Kamal. 2015. Effect of micronutrients $(\mathrm{Zn}, \mathrm{Cu}$ and $\mathrm{B})$ on photosynthetic and fruit yield attributes of citrus reticulata Blanco var. kinnow. Pak. J. Bot. 47:1241-1247.

Imtiaz, M., B.J. Alloway, K.H. Shah, S.H. Siddiqui, M.Y. Memon, M. Aslam, and P. Khan. 2003. Zinc nutrition of wheat: II: Interaction of zinc with other trace elements. Asian J. Plant Sci. 2:156-160.

Koo, R.C.J., C.A. Anderson, I. Stewart, D.P.H. Tucker, D.V. Calvert, and H.K. Wutscher. 1984. Recommended fertilizers and nutritional sprays for citrus. Florida Agricultural Expt. Sta. Bul. 536D.

Labanauskas, C. 1963. Foliar sprays correct manganese deficiencies on desert grapefruit. Calif. Agr. 17:14-15. 1 Apr. 2020. <http://hilgardia. ucanr.edu/fileaccess.cfm? article $=174679 \& p=$ SRNIQO>.

Ladaniya, M.S., R.A. Marathe, A.K. Das, C.N. Rao, A.D. Huchche, P.S. Shirgure, and A.A. Murkute. 2020. High density planting studies in acid lime (Citrus aurantifolia Swingle). Scientia Hort. 261:108935.

Li, C.P., Y. Qi, J. Zhang, L. Yang, D.H. Wang, X. Ye, N.W. Lai, L.L. Tan, D. Lin, and L.S. Chen. 2017. Magnesium-deficiency-induced alterations of gas exchange, major metabolites and key enzymes differ among roots, and lower and upper leaves of Citrus sinensis seedlings. Tree Physiol. 37:1564-1581.

Li, S.L., Z.G. Li, and Z.L. He. 2014. Effect of enhanced zinc nutrition on mitigation of Huanglongbing (HLB)-affected citrus. J. Citrus Pathol. 1:7.26 P (abstr.).

Lovatt, C.J. 1999. Timing citrus and avocado foliar nutrient applications to increase fruit set and size. HortTechnology 9:607-612.

Lovatt, C.J. 2013. Properly timing foliar-applied fertilizers increases efficacy: A review and update on timing foliar nutrient applications to citrus and avocado. HortTechnology 23:536541.

Marschner, H. 2012. Marschner's mineral nutrition of higher plants. 2nd ed. Academic Press, Cambridge, MA.

Mehlich, A. 1984. Mehlich 3 soil test extractant: A modification of Mehlich 2 extractant. Commun. Soil Sci. Plant Anal. 15:1409-1416.

Mengel, K. and E.A. Kirkby. 1980. Potassium in crop production, p. 59-110. In: N.C. Brady, ed. Advances in agronomy. Academic Press, Cambridge, MA.

Moreira, A.S., E.S. Stuchi, P.R.B. Silva, R.B. Bassanezi, E.A. Girardi, and F.F. Laranjeira. 2019. Could tree density play a role in 


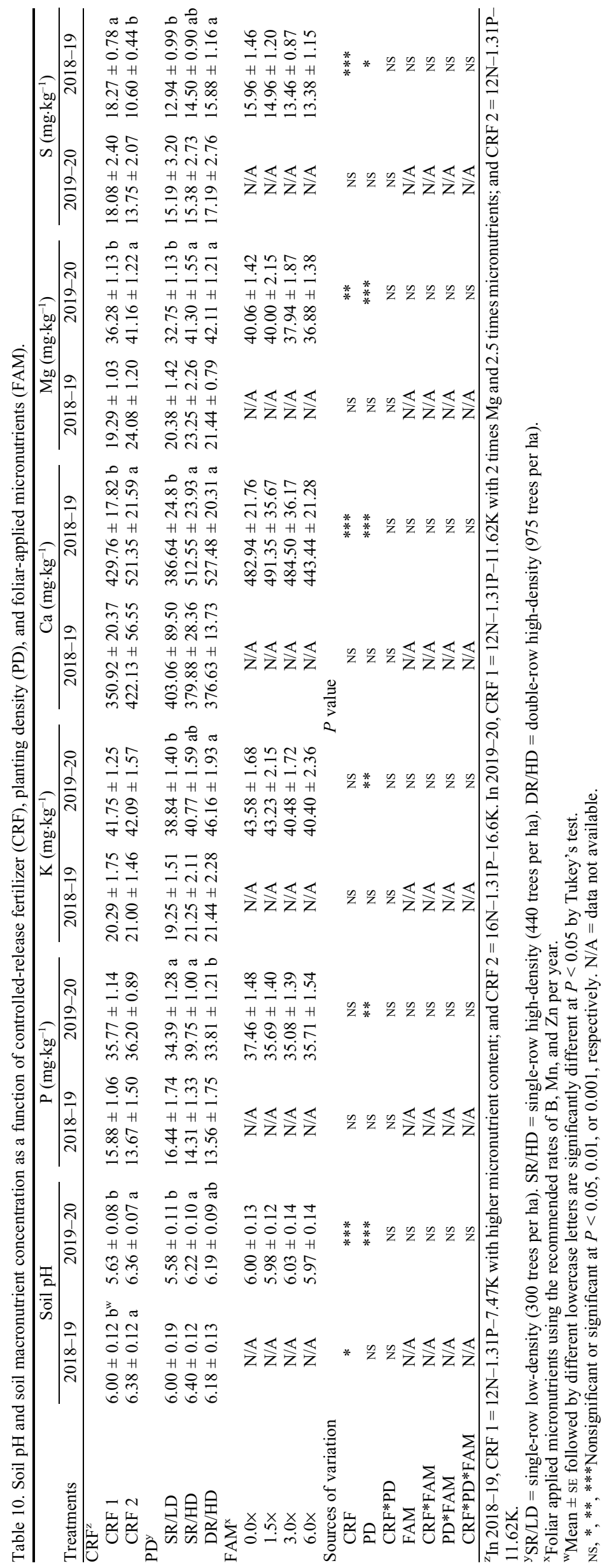

managing Citrus Huanglongbing epidemics? Trop. Plant Pathol. 44:268-274.

Morgan, J.B. and E.L. Connolly. 2013. Plant-soil interactions: nutrient uptake. Nature Educ. Knowledge 4:2. 20 Apr. 2020. <https://www. nature.com/scitable/knowledge/library/plantsoil-interactions-nutrient-uptake-105289112/>.

Morgan, K.T. and D.M. Kadyampakeni. 2020 Nutrition of florida citrus trees. 3rd ed. SL 253. Gainesville: Univ. of Florida IFAS. 5 May 2020. <http://edis.ifas.ufl.edu/pdffiles/SS/ SS47800.pdf>.

Morgan, K.T., R.E. Rouse, and R.C. Ebel. 2016 Foliar applications of essential nutrients on growth and yield of 'Valencia' sweet orange infected with Huanglongbing. HortScience 51:1482-1493.

Nasir, M., A.S. Khan, S.A. Basra, and A.U. Malik 2016. Foliar application of moringa leaf extract, potassium and zinc influence yield and fruit quality of 'Kinnow' mandarin. Scientia Hort. 210:227-235.

Nwugo, C.C., H. Lin, Y. Duan, and E.L. Civerolo 2013. The effect of 'Candidatus Liberibacter asiaticus' infection on the proteomic profiles and nutritional status of pre-symptomatic and symptomatic grapefruit (Citrus paradisi) plants. BMC Plant Biol. 13:59.

Obreza, T.A. and R.E. Rouse. 1993. Fertilizer effects on early growth and yield of Hamlin orange trees. HortScience 28:111-114.

Phuyal, D., T.A.R. Nogueira, A.D. Jani, D.M Kadyampakeni, K.T. Morgan, and R.S. Ferrarezi. 2020. 'Ray Ruby' grapefruit affected by Huanglongbing I. Planting density and soil nutrient management. HortScience, doi: 10.21273/ HORTSCI15111-20.

Pustika, A.B., S. Subandiyah, P. Holford, G.A.C. Beattie, T. Iwanami, and Y. Masaoka. 2008. Interactions between plant nutrition and symptom expression in mandarin trees infected with the disease Huanglongbing. Australas. Plant Dis. Notes 3:112-115.

Roka, F., R. Muraro, R.A. Morris, P. Spyke, K Morgan, A. Schumann, W. Castle, and E. Stover. 2009. Citrus production systems to survive greening: Economic thresholds. Proc. Florida State Hort. Soc. 122:122-126.

Rouse, R.E., M. Ozores-Hampton, F.M. Roka, and P. Roberts. 2017. Rehabilitation of Huanglongbingaffected citrus trees using severe pruning and enhanced Foliar nutritional treatments. HortScience 52:972-978.

Shen, W., J.M. Cevallos-Cevallos, U. Nunes da Rocha, H.A. Arevalo, P.A. Stansly, P.D. Roberts, and A.H.C. van Bruggen. 2013. Relation between plant nutrition, hormones, insecticide applications, bacterial endophytes, and Candidatus Liberibacter $\mathrm{Ct}$ values in citrus trees infected with Huanglongbing. Eur. J. Plant Pathol. 137:727-742.

Shin, K. and A.H.C. van Bruggen. 2018. Bradyrhizobium isolated from Huanglongbing (HLB) affected citrus trees reacts positively with primers for Candidatus Liberibacter asiaticus. Eur. J. Plant Pathol. 151:291-306.

Singerman, A., M. Burani-Arouca, and S.H. Futch 2018. The profitability of new citrus plantings in Florida in the era of Huanglongbing. HortScience 53:1655-1663.

Stansly, P.A., H.A. Arevalo, J.A. Qureshi, M.M Jones, K. Hendricks, P.D. Roberts, and F.M. Roka. 2014. Vector control and foliar nutrition to maintain economic sustainability of bearing citrus in Florida groves affected by Huanglongbing. Pest Mgt. Sci. 70:415-426.

Stover, E., W.S. Castle, and P. Spyke. 2008. The citrus grove of the future and its implications 


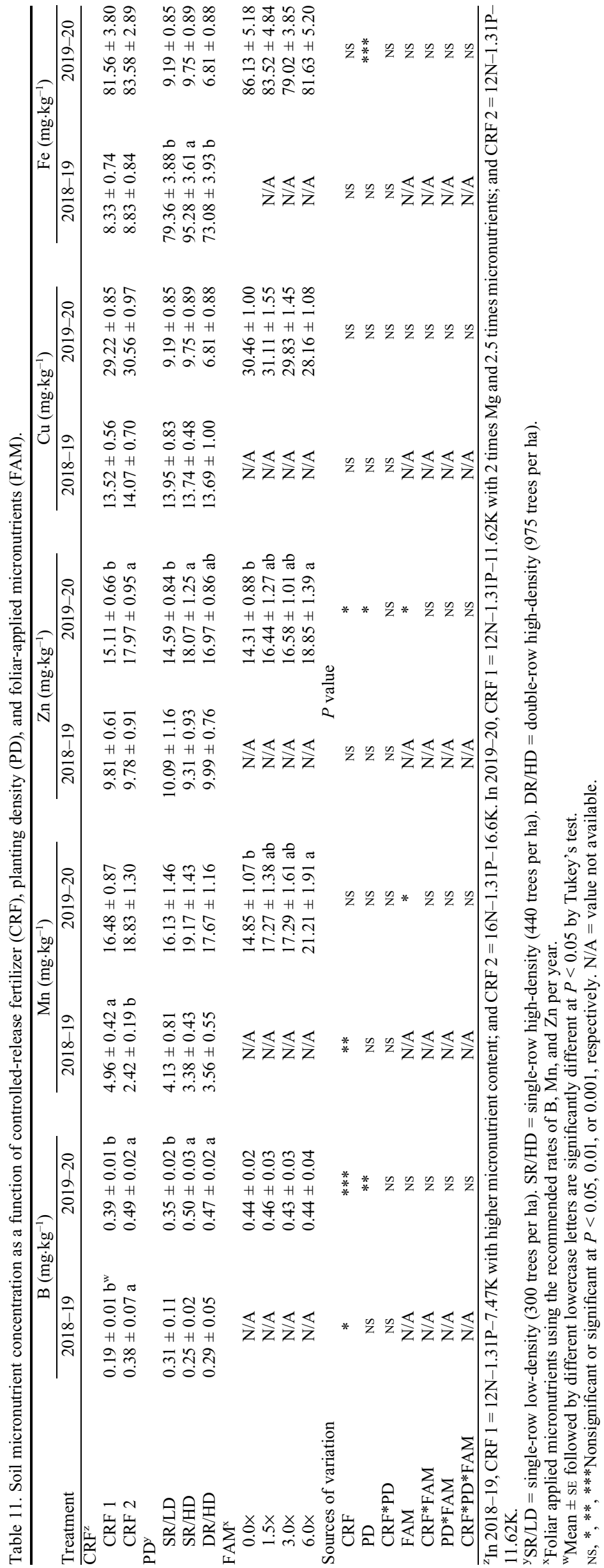

for Huanglongbing management. Proc. Florida State Hort. Soc. 121:155-159.

Sumner, M.E., P.M.W. Farina, and V.J. Hurst. 1978. Magnesium fixation - a possible cause of negative yield responses to lime applications. Commun. Soil Sci. Plant Anal. 9:9951007.

Tang, N., Y. Li, and L.S. Chen. 2012. Magnesium deficiency-induced impairment of photosynthesis in leaves of fruiting Citrus reticulata trees accompanied by up-regulation of antioxidant metabolism to avoid photo-oxidative damage. J. Plant Nutr. 175:784-793.

Tansey, J.A., P. Vanaclocha, C. Monzo, M. Jones, and P.A. Stansly. 2017. Costs and benefits of insecticide and foliar nutrient applications to Huanglongbing-infected citrus trees. Pest Mgt. Sci. 73:904-916.

Truog, E.M.I.L. 1947. Soil reaction influence on availability of plant nutrients. Soil Sci Soc. America J. 11:305-308.

U.S. Department of Agriculture. 2012. United States standards for grades of grapefruit Juice. U.S. Dept. Agr., Washington, DC. 20 June 2020. <https://www.ams.usda.gov/ sites/default/files/media/Canned_Grapefruit_Juice_Standard\%5B1\%5D.pdf $>$.

Yang, G.H., L.T. Yang, H.X. Jiang, Y. Li, P. Wang, and L.S. Chen. 2012. Physiological impacts of magnesium-deficiency in citrus seedlings: Photosynthesis, antioxidant system and carbohydrates. Trees 26:12371250.

Zekri, M. and T. Obreza. 2018. Micronutrient deficiencies in citrus: Iron, zinc, and manganese. SL 204. Univ. of Florida IFAS, Gainesville. 20 Apr. 2020. <https://edis.ifas.ufl.edu/pdffiles/SS/SS42300.pdf>.

Zekri, M. and T. Obreza. 2019. Magnesium $(\mathrm{Mg})$ for citrus trees. SL 380. Univ. of Florida IFAS, Gainesville. 20 Apr. 2020. <https://edis.ifas.ufl.edu/pdffiles/SS/SS58200.pdf>

Zhang, M.Q., Y. Guo, C.A. Powell, M.S. Doud, C.Y. Yang, H. Zhou, and Y.P. Duan. 2016. Zinc treatment increases the titer of 'Candidatus Liberibacter asiaticus' in Huanglongbing-affected citrus plants while affecting the bacterial microbiomes. J. Appl. Microbiol. 120:16161628.

Zhu, D., W. Juan, S. Liao, and W. Liu. 2007. Relationship between plant availability of boron and the physico-chemical properties of boron in soils, p. 345-354. In: F. Xu, H.E. Goldbach, P.H. Brown, et al. Advances in plant and animal boron nutrition. Springer, Dordrecht, The Netherlands. 